Prepared in cooperation with the National Integrated Drought Information System

\title{
Coastal Salinity Index Along the Southeastern Atlantic Coast and the Gulf of Mexico, 1983 to 2018
}

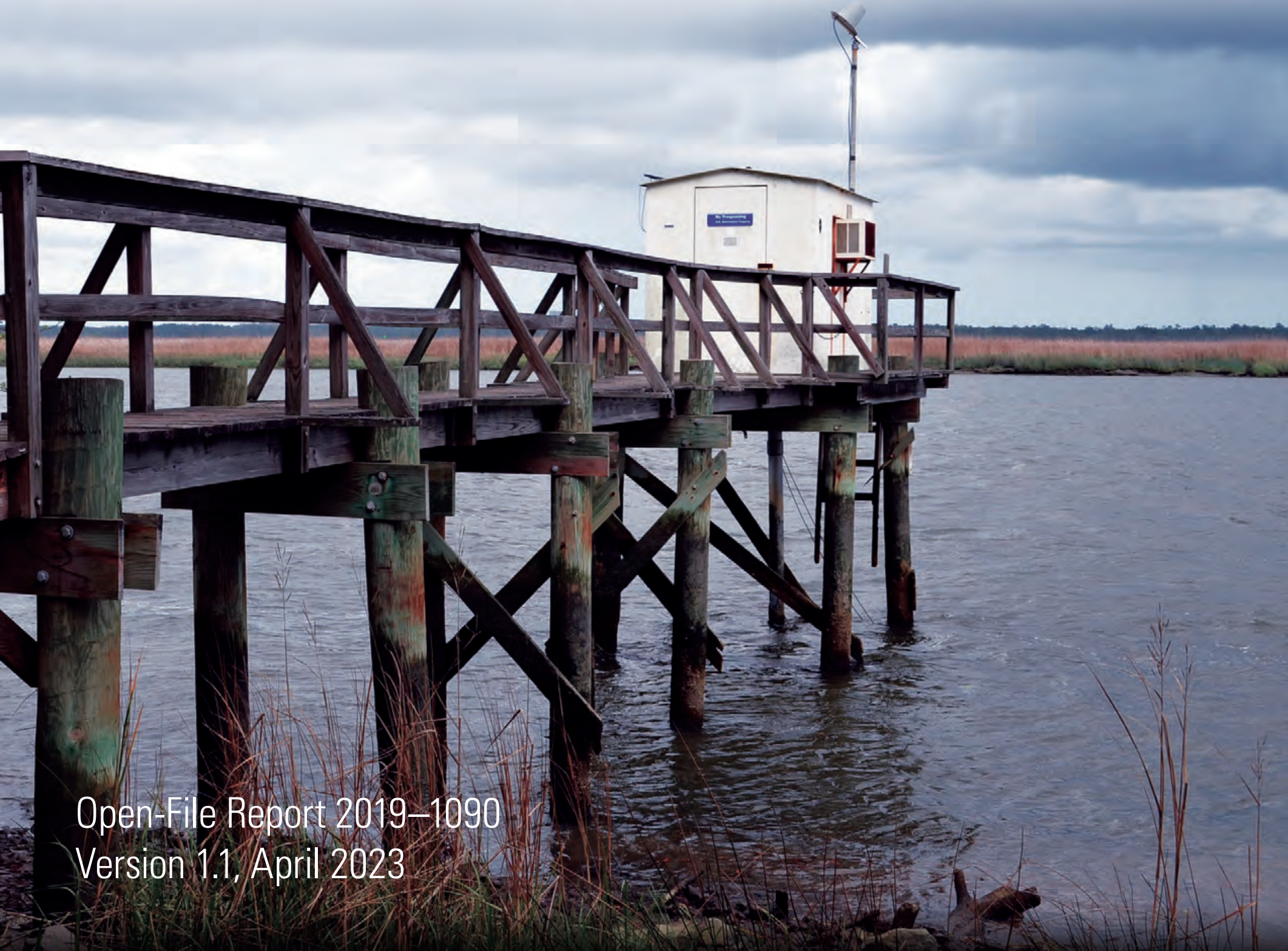

U.S. Department of the Interior U.S. Geological Survey 
Cover. U.S. Geological Survey station 02172053 on the Cooper River at Mobay near North Charleston, South Carolina. Photograph by U.S. Geological Survey. 


\section{Coastal Salinity Index Along the Southeastern Atlantic Coast and the Gulf of Mexico, 1983 to 2018}

By Matthew D. Petkewich, Kirsten Lackstrom, Bryan J. McCloskey, Lauren F. Rouen, and Paul A. Conrads

Prepared in cooperation with the

National Integrated Drought Information System

Open-File Report 2019-1090

Version 1.1, April 2023 


\title{
U.S. Department of the Interior DAVID BERNHARDT, Secretary
}

\section{U.S. Geological Survey James F. Reilly II, Director}

\author{
U.S. Geological Survey, Reston, Virginia \\ First release: 2019 \\ Revised: April 2023 (ver. 1.1)
}

For more information on the USGS —-the Federal source for science about the Earth, its natural and living resources, natural hazards, and the environment-visit https://www.usgs.gov or call 1-888-ASK-USGS.

For an overview of USGS information products, including maps, imagery, and publications,

visit https://store.usgs.gov.

Any use of trade, firm, or product names is for descriptive purposes only and does not imply endorsement by the U.S. Government.

Although this information product, for the most part, is in the public domain, it also may contain copyrighted materials as noted in the text. Permission to reproduce copyrighted items must be secured from the copyright owner.

Suggested citation:

Petkewich, M.D., Lackstrom, K., McCloskey, B.J., Rouen, L.F, and Conrads, P.A., 2019, Coastal Salinity Index along the southeastern Atlantic coast and the Gulf of Mexico, 1983 to 2018 (ver. 1.1, April 2023): U.S. Geological Survey Open-File Report 2019-1090, 26 p., https://doi.org/10.3133/ofr20191090. 


\section{Acknowledgments}

The complexity of this study required interagency cooperation in addition to individual contributions. The authors thank the National Oceanic and Atmospheric Administration (NOAA) National Integrated Drought Information System (NIDIS) for funding the further development and distribution of the Coastal Salinity Index. The authors also thank the funding agencies that support the Everglades Depth Estimation Network (EDEN) project- -the U.S. Army Corps of Engineers, Jacksonville District, and the U.S. Geological Survey (USGS) Greater Everglades Priority Ecosystems Science Program. EDEN funds supported the development of the Coastal Salinity Index $R$ package and data analysis for this investigation. The authors also thank NOAA's Climate Program Office and the Regional Integrated Sciences and Assessments (RISA) program for funding the Carolinas Integrated Sciences and Assessments (CISA) team's participation in this project. The RISA program supports interdisciplinary teams that conduct applied climate research and sustained engagement to help communities address the risks and effects of climate and extreme weather events. Greg Carbone (University of South Carolina/CISA), Junyu Lu (University of South Carolina/CISA), Christopher Swarzenski (USGS), and Simeon Yurek (USGS) provided greatly appreciated technical support and advice during this investigation. The authors also thank the USGS and NIDIS reviewers for their thoughtful reviews and constructive comments. 


\section{Contents}

Acknowledgments .......................................................................................................................ii

Abstract

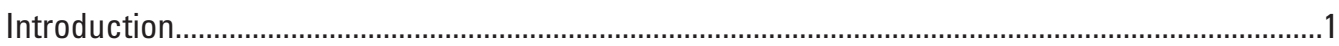

Purpose

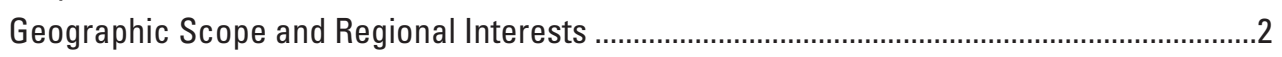

Development of the Coastal Salinity Index................................................................................

Refinement and Dissemination of the Coastal Salinity Index...................................................

Development of the R Package for Coastal Salinity Index Computation....................................4

Computation of the Coastal Salinity Index for Locations in the South Atlantic and Gulf of Mexico

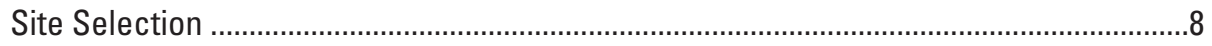

ScienceBase Dissemination .......................................................................................10

Computation and Dissemination of Real-time Coastal Salinity Index Results..........................10

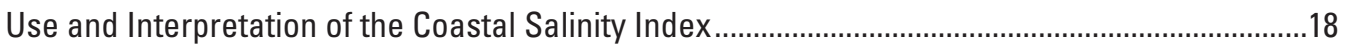

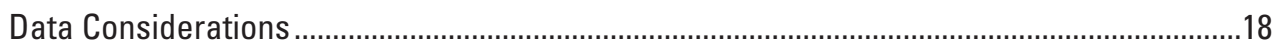

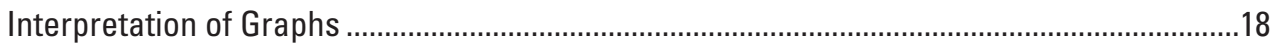

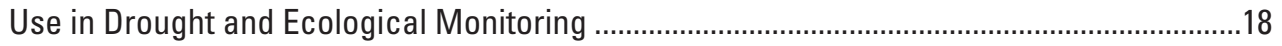

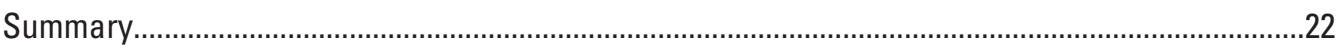

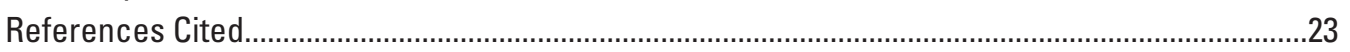

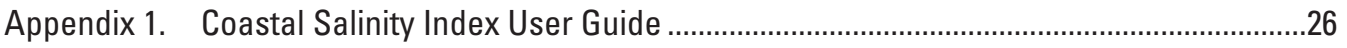




\section{Figures}

1. Schematic showing location of the freshwater-saltwater divide in response to freshwater and saltwater flows.....

2. Graph showing cumulative frequency curve for the 6-month Coastal Salinity Index for Cooper River near Goose Greek, South Carolina, for the period July 1984 to September 2018.

3. Graphs showing 1-month, 12-month, and 24-month Coastal Salinity Index computations for McCormick Creek at mouth near Key Largo, Florida, for the period October 1995 to December 2018.

4. Graph showing stacked Coastal Salinity Index computations for McCormick Creek at mouth near Key Largo, Florida, for the period October 1995 to December 2018 ...........9

5. Screen capture showing an example Coastal Salinity Index R package output file, with CSI intervals as column headers and individual months as rows.....

6. Map showing locations of the water-quality sites used in the Coastal Salinity Index calculations

7. Graphs from the Coastal Everglades Depth Estimation Network web page showing real-time water elevation, Coastal Salinity Index, and salinity duration for McCormick Creek at mouth near Key Largo, Florida

8. Maps showing locations of the watersheds and National Estuarine Research Reserve System stations near Winyah Bay and North Inlet, South Carolina...................19

9. Graphs showing Coastal Salinity Index results for National Estuarine Research Reserve System stations near Winyah Bay and North Inlet, South Carolina..................20

10. Graph showing Coastal Salinity Index results for Waccamaw River near Pawley's Island, South Carolina.

\section{Tables}

1. Coastal salinity classifications, descriptions, and threshold values .5

2. Station numbers, station names, dates, and locations of sites used in the Coastal Salinity Index calculations 


\section{Conversion Factors}

Temperature in degrees Celsius $\left({ }^{\circ} \mathrm{C}\right)$ may be converted to degrees Fahrenheit $\left({ }^{\circ} \mathrm{F}\right)$ as ${ }^{\circ} \mathrm{F}=\left(1.8 \times{ }^{\circ} \mathrm{C}\right)+32$.

\section{Datum}

Vertical coordinate information is referenced to the North American Vertical Datum of 1988 (NAVD 88).

Horizontal coordinate information is referenced to the North American Datum of 1983 (NAD 83).

\section{Supplemental Information}

Specific conductance is given in microsiemens per centimeter at 25 degrees Celsius $\left(\mu \mathrm{S} / \mathrm{cm}\right.$ at $\left.25^{\circ} \mathrm{C}\right)$.

\section{Abbreviations}

$\begin{array}{ll}\text { CERP } & \text { Comprehensive Everglades Restoration Plan } \\ \text { CISA } & \text { Carolinas Integrated Sciences and Assessments } \\ \text { CSI } & \text { Coastal Salinity Index } \\ \text { DEWS } & \text { Drought Early Warning System } \\ \text { EDEN } & \text { Everglades Depth Estimation Network } \\ \text { NEP } & \text { National Estuary Program } \\ \text { NERRS } & \text { National Estuarine Research Reserve System } \\ \text { NIDIS } & \text { National Integrated Drought Information System } \\ \text { NOAA } & \text { National Oceanic and Atmospheric Administration } \\ \text { NWIS } & \text { National Water Information System } \\ \text { pPt } & \text { parts per thousand } \\ \text { RISA } & \text { Regional Integrated Sciences and Assessments } \\ \text { RESTORE } & \text { Resources and Ecosystems Sustainability, Tourist Opportunities, and Revived } \\ & \text { Economies of the Gulf Coast States } \\ \text { SCDNR } & \text { South Carolina Department of Natural Resources } \\ \text { SWMP } & \text { System Wide Monitoring Program } \\ \text { SPI } & \text { Standardized Precipitation Index } \\ \text { USGS } & \text { U.S. Geological Survey } \\ \text { NPS } & \text { U.S. National Park Service }\end{array}$




\title{
Coastal Salinity Index Along the Southeastern Atlantic Coast and the Gulf of Mexico, 1983 to 2018
}

\author{
By Matthew D. Petkewich, ${ }^{1}$ Kirsten Lackstrom, ${ }^{2}$ Bryan J. McCloskey, ${ }^{3}$ Lauren F. Rouen, ${ }^{2}$ and Paul A. Conrads ${ }^{4}$
}

\section{Abstract}

Coastal droughts have a different dynamic than upland droughts, which are typically characterized by agricultural, hydrologic, meteorological, and (or) socioeconomic effects. Drought uniquely affects coastal ecosystems because of changes in the salinity conditions of estuarine creeks and rivers. The location of the freshwater-saltwater interface in surface-water bodies is an important factor in the ecological and socioeconomic dynamics of coastal communities. To address the data and information gap for characterizing coastal drought, the Coastal Salinity Index (CSI) was developed by using salinity data. The CSI uses a computational approach similar to the Standardized Precipitation Index. The CSI can be computed for unique time intervals (for example 1-, 6-, 12-, and 24-month intervals) to characterize short- and long-term drought (saline) conditions, as well as wet (high freshwater inflow) conditions.

To encourage the use of the CSI in current and future research endeavors, this investigation addressed three activities to enhance the use and application of the CSI. First, a software package was developed for the consistent computation of the CSI that includes preprocessing of salinity data, filling missing data, computing the CSI, post-processing, and generating the supporting metadata. This software package is available for download from the U.S. Geological Survey GitLab repository. Second, the CSI has been computed at sites along the southeastern Atlantic coast (Florida to North Carolina) and the Gulf of Mexico (Texas to Florida) to increase the opportunity for linking the CSI to ecological response data. Third, using telemetered salinity data, the real-time computation of the CSI has been prototyped and disseminated on the web.

\footnotetext{
${ }^{1}$ U.S. Geological Survey.

${ }^{2}$ Carolinas Integrated Sciences and Assessments.

${ }^{3}$ Cherokee Nation Technology Solutions, LLC, under contract to the U.S. Geological Survey.

${ }^{4}$ U.S. Geological Survey, deceased.
}

\section{Introduction}

Droughts in coastal areas have a different dynamic than upland droughts. Commonly used drought indices typically characterize agricultural, hydrologic, and meteorological conditions; however, they do not incorporate salinity, a key stressor associated with coastal drought, or changing salinity dynamics, which can be affected by local or regional-scale drought events. In part, motivation for a coastal drought index came from the National Oceanic and Atmospheric Administration (NOAA) National Integrated Drought Information System (NIDIS) Drought Early Warning System (DEWS) for coastal North Carolina and South Carolina. The DEWS convenes stakeholders from a broad range of agencies and sectors to address drought monitoring, research, planning, and communication needs at the regional level (National Integrated Drought Information System, 2017a). Launched in 2012, the Coastal Carolinas DEWS has focused on (1) improving understanding of the unique vulnerabilities and effects of drought on coastal ecosystems and (2) developing tools, information, and other resources to help managers and decision makers integrate drought and coastal resource management activities. Stakeholders identified project areas and goals for the Coastal Carolinas DEWS at a scoping workshop (Brennan and others, 2012); a key priority was the development of a drought index that would incorporate salinity. This tool would be used to monitor changing salinities in coastal surface-water bodies, as well as the associated effects on estuarine habitats and freshwater availability for ecological, municipal, and industrial needs.

In 2013, the NIDIS provided funding to the U.S. Geological Survey (USGS) to assess the feasibility of creating a coastal drought index using salinity data. This initial effort led to the development and assessment of the Coastal Salinity Index (CSI) for two sites along the South Carolina coast (Conrads, 2016; Conrads and Darby, 2017). The project demonstrated that the index could be used to delineate short- and long-term drought and wet conditions; however, to advance the use of the CSI as a general drought monitoring tool, widerranging CSI calculations need to be available to the scientific 
community. To build on the pilot study, the USGS and collaborators from the Carolinas Integrated Sciences and Assessments (CISA) team identified three general activities to refine and further develop the CSI for applications in the Southeastern and Southern United States. In 2017, the USGS in cooperation with the NIDIS and CISA began a 2-year investigation to (1) build a unified CSI calculation and visualization software platform, (2) release CSI calculations for many coastal locations, and (3) disseminate near real-time web-based CSI results. In addition, CISA and the USGS established a CSI working group for the Carolinas with the goal of obtaining feedback on the CSI tool development.

\section{Purpose}

This report describes the tool created to calculate the CSI and the efforts involved to disseminate CSI analytical results for 97 coastal gaging stations in the Southeastern United States and the Gulf of Mexico. Historic CSI results for all 97 stations are available through the USGS ScienceBase repository (Petkewich and others, 2019; https://doi.org/10.5066/ P9MQLNL2). In this report, "historic CSI calculations" refers to results that have been calculated once for a specific site and specific time period and will not be updated. CSIs are also available on a near real-time basis for 29 of those 97 stations - 17 stations in the South Atlantic and 12 stations in the Florida Everglades. The near real-time CSIs are calculated daily and include salinity data from the beginning of the period of record through the previous day. For simplicity, these calculations will be called "real-time" in this report. In addition, this report provides information for consideration in the use and interpretation of the CSI.

In support of the USGS Water Resources Mission Area (https://www.usgs.gov/mission-areas/water-resources), this investigation provides data and information to protect and enhance water resources for human health, aquatic health, and environmental quality. The real-time dissemination of the CSI addresses the USGS water science goal of "delivering timely hydrologic data, analyses, and decision-support tools seamlessly across the Nation to support water-resource decisions" (Evenson and others, 2012, p. 2).

Real-time CSI data allow managers and decision makers to "detect and respond to emergencies related to water-quality degradation" (Evenson and others, 2012, p. 33). The current multidisciplinary study also addresses the USGS Integrated Drought Science Plan goal of providing "decision-support tools and technologies to stakeholders for enhancing drought resilience, adaptation, and mitigation" (Ostroff and others, 2017 , p. 2). Benefits of this investigation to NIDIS and coastal resource managers include (1) the development of a publicly available, citable, and uniform software package for the accurate and consistent computation and visualization of the CSI and (2) the development of two websites for real-time CSI dissemination on the internet. In addition, the publication of the 97 historic CSIs at selected locations along the southeastern
Atlantic coast and the Gulf of Mexico provides reference salinity conditions for coastal resource managers and ecologists to correlate to their various subjects of interest.

The USGS uses rating tables developed for the conversion of specific conductance in microsiemens per centimeter at 25 degrees Celsius to salinity recorded in practical salinity units or parts per thousand. Salinity expressed in practical salinity units is nearly equivalent to parts per thousand in these conditions (Wagner and others, 2006). In this report, the CSI results are calculated using either raw salinity data or salinity data derived from field specific conductance values; however, for purposes of discussion, specific conductance and salinity can be considered interchangeable.

\section{Geographic Scope and Regional Interests}

The geographic scope of this project is the southeastern and southern coastline of the United States, including the Gulf and Atlantic coasts, from Texas to North Carolina, as well as Puerto Rico. Estuaries and lagoons in these coastal areas provide benefits such as fish habitat, storm protection, water supply, and recreation opportunities (Barbier and others, 2011). The location of the freshwater-saltwater interface in surface-water bodies is an important factor in the ecological and socioeconomic dynamics of coastal communities. Changes in the freshwater-saltwater balance have the potential to affect the uses and benefits of these systems.

Specifically, the coastal oligohaline wetlands zone (sometimes referred to as the "coastal fringe" or the "zone of change") is critical in evaluating the hydrologic and ecological responses to modifications of the water delivery system related to habitat restoration and future climate change. In the short term (days to weeks), water levels and salinity dynamics are affected by tides, wind, floods, and storm events (fig. 1). Regulation of releases from upstream reservoirs that alter downstream streamflows, as well as water withdrawals for agriculture, municipalities, and industry, also affect freshwater availability in the coastal zone. Over longer periods of time (months to decades), drought, increased water use, and sea-level rise can increase saltwater inundation. Hydrologic changes, either from flow alterations or climate change, will first be manifested along the coastal fringe. Coastal fringe areas experience tidal backwater conditions; increases in streamflow would move this area seaward, whereas sea-level rise would move this area inland. Coastal areas will probably exhibit larger relative changes in hydroperiods as compared to inland areas (Conrads and others, 2018).

Many efforts in the region seek to better understand and monitor salinity dynamics and the effects on ecological and human systems. The application of the CSI and the linkage to coastal resources addresses interests of many State and Federal agencies, universities, coastal resource managers, coastal ecologists, and the drought community. Within the Department of the Interior, units such as the U.S. Fish and Wildlife Service National Wildlife Refuge System, the National Park Service 


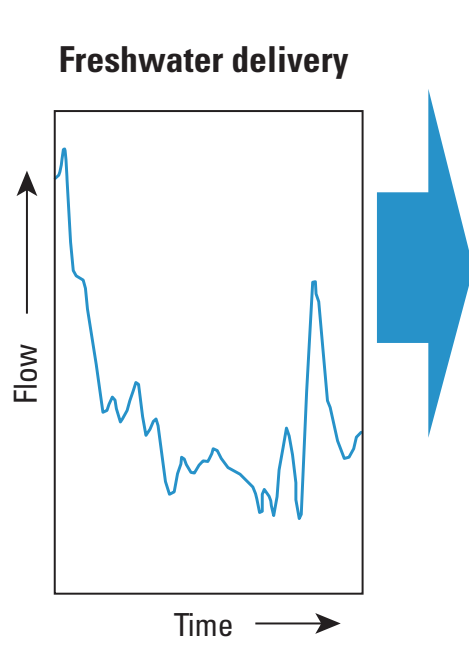

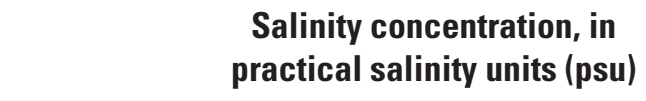

\section{practical salinity units (psu)}

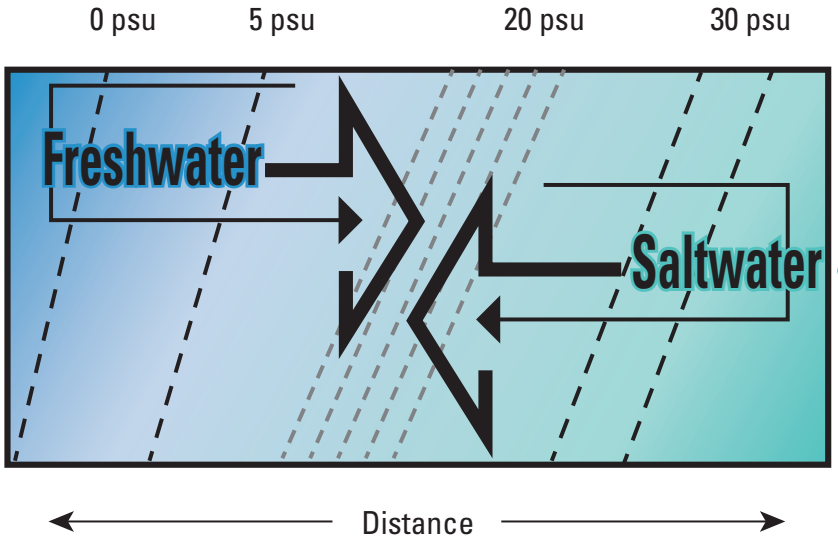

Marine water level

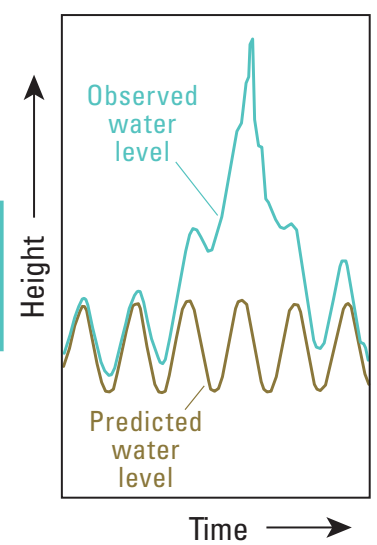

Figure 1. Location of the freshwater-saltwater divide in response to freshwater and saltwater flows. Figure from Conrads and others (2018).

(NPS), and the USGS Water and Ecosystems Mission Areas conduct biotic and abiotic (including water quality) monitoring as part of their resource management missions. Over 70 National Wildlife Refuges are located within the geographic scope of this project. The NPS Southeast Coast Inventory and Monitoring Network has conducted long-term monitoring at nine park units in coastal North Carolina, South Carolina, Georgia, and Florida (Gregory and others, 2013). As of 2019, the USGS has a network of over 1,200 salinity gages, many of which are along the coast (U.S. Geological Survey, 2019).

In central and southern Florida, the Comprehensive Everglades Restoration Plan (CERP) guides projects designed to restore, protect, and preserve the area's water resources. The Coastal Everglades Depth Estimation Network (EDEN) website was developed to provide access to stage, temperature, and salinity data for researchers interested in the interaction of salinity, climate, and managed freshwater flow to the coastal portions of the Florida Everglades. Salinity, along with water temperature, is a critical variable for the biological viability of many species and is the basis for many of the CERP performance measures. Major ecosystem restoration efforts along the Gulf Coast may also provide opportunities to apply the CSI. As a consequence of the Deepwater Horizon oil spill, the Resources and Ecosystems Sustainability, Tourist Opportunities, and Revived Economies of the Gulf Coast States Act (RESTORE) was enacted to rehabilitate the long-term health of the Gulf of Mexico. RESTORE is funding research evaluating ecological flows to the Gulf and the effect of flows on coastal ecosystems. The CSI could be a useful tool in studies to improve understanding of the correlations between flows and coastal ecology.

The NOAA National Estuarine Research Reserve System (NERRS) leads research, stewardship, and education activities at 29 sites across the country, 11 of which are in the Southern United States and Puerto Rico. The network engages with local communities to protect estuarine habitats, water quality, and water quantity and expand understanding of the various biophysical and socioeconomic processes that affect estuarine systems. The System Wide Monitoring Program (SWMP), established in 1995, collects and maintains long-term data on water quality, weather, biological communities, habitat, and land-use and land-cover characteristics (National Oceanic and Atmospheric Administration Office for Coastal Management, 2017). The U.S. Environmental Protection Agency's National Estuary Program (NEP) supports place-based programs focused on restoring and maintaining water quality and the ecological integrity of estuarine systems and their watersheds. Of the 28 NEP sites in the United States, 10 are within the geographic scope of this project. The NEP develops a Comprehensive Conservation Management Plan for each site to address stakeholder-identified water-quality and environmental-protection priorities (U.S. Environmental Protection Agency, 2009). In addition, the NIDIS DEWS programs for the Coastal Carolinas, Apalachicola Chattahoochee Flint River Basin, and Southern Plains all recognize the need to improve management of drought effects caused by increased salinity (National Integrated Drought Information System, 2017a, b, c). 


\section{Development of the Coastal Salinity Index}

Existing drought indices do not incorporate salinity, the primary stressor associated with coastal drought, or the multiple factors that contribute to high salinity conditions, such as precipitation, streamflow, sea level, tides, and wind. The availability of real-time and historical salinity datasets provided an opportunity for the development of a salinity-based coastal drought index.

Conrads and Darby (2017) developed the CSI using an approach similar to the Standardized Precipitation Index (SPI), a readily available drought index that is widely used for monitoring meteorological droughts (McKee and others, 1993). The SPI uses precipitation data to develop a probability distribution of precipitation for a given location. It is a flexible indicator in that it can be calculated for several time scales (for example, 1 to 24 months or longer), used with datasets of varying record lengths and with missing data, and used to compare conditions in different climate regimes (World Meteorological Organization and Global Water Partnership, 2016).

The CSI substitutes total monthly precipitation with monthly mean salinity data to determine the probability of recording a given salinity value in a particular month. For the CSI, monthly mean salinity data are fit to a gamma distribution and then normalized (mean of zero and standard deviation of one). The index values are standard deviations from the normalized mean values. To align the CSI values with the same classification scheme used by the U.S. Drought Monitor, the CSI values were multiplied by -1 so that negative numbers represent drought conditions. An index value of zero indicates historical mean salinity; negative and positive values represent increasingly saline and fresh conditions, respectively. Typical SPI threshold values were adopted for the coastal drought classifications (table 1; fig. 2). The thresholds characterize the historical range of measured salinity data at the site and provide an indication of the severity of the saline (or freshwater) conditions over the interval for which the CSI was computed. As with the SPI, the CSI can be computed for various time intervals, allowing the CSI to be used to evaluate and compare short- and long-term drought (saline) and wet (freshwater) conditions. Preliminary evaluation of the CSI indicates that the index can be used for regional/shoreline comparison between estuaries and as an index for wet conditions (high freshwater inflow) in addition to drought (saline) conditions (Conrads and Darby, 2017).

\section{Refinement and Dissemination of the Coastal Salinity Index}

The initial effort to develop the CSI used data from two USGS water-quality stations in large drainage basins - the Yadkin-Pee Dee and Savannah River Basins (Conrads, 2016;
Conrads and Darby, 2017). For the CSI to be broadly useful as a drought monitoring tool, it is necessary to expand comparisons and analyses beyond the two original sites. In 2017, the USGS cooperated with the NIDIS and CISA to further develop and disseminate the CSI. This section presents the results of the three primary tasks involved in this investigation:

1. Development of a unified CSI software platform,

2. Computation of CSIs for many coastal locations, and

3. Dissemination of the real-time, web-based CSI results.

To encourage the use of the CSI in current and future investigations, there is a need to disseminate CSI results for many sites as historic and (or) real-time calculations. The distribution of CSI data will allow researchers to investigate the possible relations between their subjects of interest and the calculated CSI results. In addition, the distribution of a uniform CSI R package will allow interested coastal resource agencies, researchers, students and others to compute and visualize CSIs in a consistent method for their sites of interest for appropriate investigation periods.

\section{Development of the R Package for Coastal Salinity Index Computation}

The initial development of the CSI used multiple software packages and programs to analyze data, estimate missing data, compute the index, and plot data. The objective of this task was to facilitate the use of the CSI by numerous researchers and agencies by developing an easily accessible software package for the consistent computation of the CSI. The software package described here addresses the preprocessing of salinity data, estimating missing data, computing the CSI, postprocessing, and documenting the supporting metadata. The package is available online to provide continuity with regards to user access while allowing modifications and version updates to the computer code as needed.

The R programing language was the platform for developing the CSI. The R language is widely used in the scientific community and is an open-source programing language specially designed for statistics, data analysis, and visualization (R Core Team, 2013). It is highly extensible and has a large community of contributors frequently adding functionality. This large community makes $\mathrm{R}$ one of the most powerful and diverse software packages for scientific computing and data processing. R packages include all the necessary functions for a particular analysis, including data input, common data preparation steps, computation, tabular and graphical output, version control, version testing, and archiving. $\mathrm{R}$ packages are an ideal way to package, distribute, and publish the $\mathrm{R}$ code and data for re-use by others through the Comprehensive R Archive Network (CRAN) or the U.S. Geological Survey GitLab repository. 
Table 1. Coastal salinity classifications, descriptions, and threshold values.

[Brackets and parentheses in the ranges indicate inclusion (brackets) or exclusion (parentheses) of a value in the listed range. CSI, Coastal Salinity Index; CD, coastal drought; NA, not applicable; CW, coastal wet; $\infty$, infinity]

\begin{tabular}{|c|c|c|c|c|c|}
\hline $\begin{array}{l}\text { Coastal salinity } \\
\text { classification }\end{array}$ & Description & Color & Range & $\begin{array}{c}\text { CSI } \\
\text { threshold } \\
\text { value }\end{array}$ & $\begin{array}{l}\text { Cumulative } \\
\text { percentage }\end{array}$ \\
\hline CD4 & Exceptional salinity conditions & & $(\infty,-2]$ & -2 & 2 \\
\hline CD3 & Extreme salinity conditions & & $(-2.0$ to -1.6$]$ & -1.6 & 5 \\
\hline $\mathrm{CD} 2$ & Severe salinity conditions & & $(-1.6$ to -1.3$]$ & -1.3 & 10 \\
\hline CD1 & Moderate salinity conditions & & $(-1.3$ to -0.8$]$ & -0.8 & 20 \\
\hline $\mathrm{CD} 0$ & Abnormal salinity conditions & & $(-0.8$ to -0.5$]$ & -0.5 & 30 \\
\hline Normal & Normal salinity conditions & & $(-0.5$ to 0.5$]$ & NA & 70 \\
\hline CW0 & Abnormal freshwater conditions & & $(0.5$ to 0.8$]$ & 0.5 & 80 \\
\hline CW1 & Moderate freshwater conditions & & $(0.8$ to 1.3$]$ & 0.8 & 90 \\
\hline CW2 & Severe freshwater conditions & & (1.3 to 1.6$]$ & 1.3 & 95 \\
\hline CW3 & Extreme freshwater conditions & & (1.6 to 2.0$]$ & 1.6 & 98 \\
\hline CW4 & Exceptional freshwater conditions & & $(2, \infty)$ & 2 & 100 \\
\hline
\end{tabular}

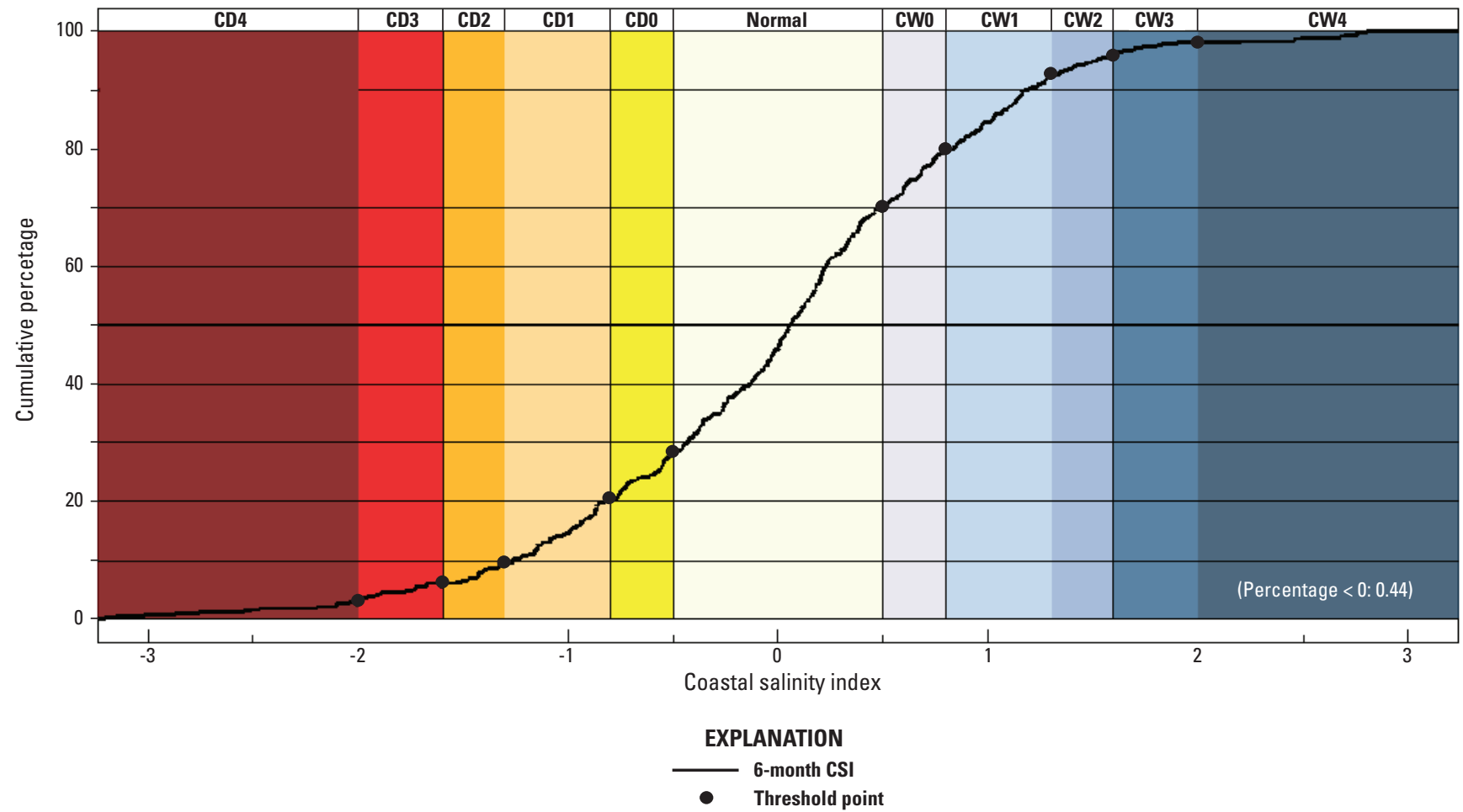

Figure 2. Cumulative frequency curve for the 6-month Coastal Salinity Index (CSI-6) for Cooper River near Goose Greek, South Carolina (U.S. Geological Survey station 0217050), for the period July 1984 to September 2018. CD, coastal drought; CW, coastal wet. 
The CSI R package can be downloaded from the USGS GitLab website (https://code.usgs.gov/water/eden/CSI). The CSI R package includes seven primary functions:

1. Importing salinity (or specific conductance) data from external files (CSIimport*),

2. Converting specific conductance values to salinity, if necessary (CSIspec_con),

3. Estimating missing values by interpolation (CSIinterp),

4. Calculating CSI values (CSIcalc),

5. Plotting individual CSI results (CSIplot),

6. Plotting stacked CSI results (CSIstack), and

7. Exporting tabular CSI results (CSIwrite).

Detailed descriptions of these and other CSI functions are available in the $\mathrm{R}$ package help pages; general descriptions of these seven functions are listed below.

Importing salinity (or specific conductance) data from external files-Several functions are available for importing data into R. The package can process hourly (CSIimport unit), daily (CSIimport_daily), or monthly (CSSIimport_monthly) data or data of variable timestamps (every 6,15 , or 30 minutes; intermittent; and so on), producing a data object containing monthly mean values. Because the NERRS SWMP maintains an extensive, longterm salinity dataset, a function was also created to import data downloaded from NERRS into the package without the need for data editing or formatting (CSIimport_NERRS).

Converting specific conductance values to salinity - With the CSIspec_con function, specific conductance data (compensated to 25 degrees Celsius $\left[{ }^{\circ} \mathrm{C}\right]$ and 760 -millimeter atmospheric pressure) can be converted to salinity ( $S$, unitless or often expressed as practical salinity units) using the following equation (Schemel, 2001; Wagner and others, 2006):

$$
\begin{aligned}
S= & K_{1}+\left(K_{2} \times R^{1 / 2}\right)+\left(K_{3} \times R\right)+\left(K_{4} \times R^{3 / 2}\right) \\
& +\left(K_{5} \times R^{2}\right)+\left(K_{6} \times R^{5 / 2}\right)
\end{aligned}
$$

$$
\begin{aligned}
\text { where } & \\
K_{1}= & 0.0120, \\
K_{2}= & -0.2174, \\
K_{3}= & 25.3283, \\
K_{4}= & 13.7714, \\
K_{5}= & -6.4788, \\
K_{6}= & 2.5842, \\
\text { and } R \quad= & \text { the ratio of the measured specific } \\
& \text { conductance to that of standard } \\
& \text { seawater (salinity equals } 35 \text { ) at } 25^{\circ} \mathrm{C} \\
& (53,087 \text { microsiemens per centimeter) } \\
& \text { (Wagner and others, 2006) } .
\end{aligned}
$$

The USGS uses rating tables developed for this conversion and the conversion of specific conductance to salinity in parts per thousand (Miller and others, 1988) to process corrected specific conductance records within the National Water Information System (NWIS) database (U.S. Geological Survey, 2003).

Estimating missing values by interpolation-The CSIinterp function allows interpolation of missing mean monthly values (listed as "NA" in the input data file) using linear or spline routines that interpolate between the two data values that bracket the missing data (Zeileis and others, 2018). Experimentation with removal of available data indicated that CSI calculations for datasets with at least 15 days of data for each month produced similar CSI classifications for datasets with and without missing data. Monthly averages are created from whichever data values are present for the month, so some initial user cleanup of data may be advisable before data input. The CSIinterp function by default limits the estimation to a maximum of 6 months of missing data; however, that time span is adjustable, if needed. Data processors should use their discretion to determine if interpolation is appropriate for the estimation of missing data, and if so, the appropriate maximum gap in data to be estimated by interpolation. A spline interpolation option is available for when that type of interpolation might be more appropriate than linear interpolation.

Calculating CSI values-The CSIcalc function calculates monthly CSI values from salinity data for a range of time scales. For example, the 6-month scale uses the mean of each individual month and the preceding 5 months to obtain the CSI value. By default, CSI values are calculated for all scales from 1 to 24 months; however, this may be adjusted by the user to any 1 - to $n$-month range. Currently, the R package is written to calculate CSI values for monthly mean salinity data; however, there is no intrinsic reason the CSI calculations could not be applied to data of other time scales - for example, weekly, biweekly, or quarterly mean data. In the future, the package functionality may be extended to allow for this flexibility.

Plotting individual CSI results - The CSIplot function produces 24 CSI graphs depicting each calculation of the CSI using intervals of 1 to 24 months for the moving monthly average values. The computed 1-month CSI for McCormick Creek near Key Largo, Florida (USGS station 251003080435500), is shown as an example in figure $3 A$. The CSI graph displays a black line representing the moving monthly average salinity value for the input period of record and 

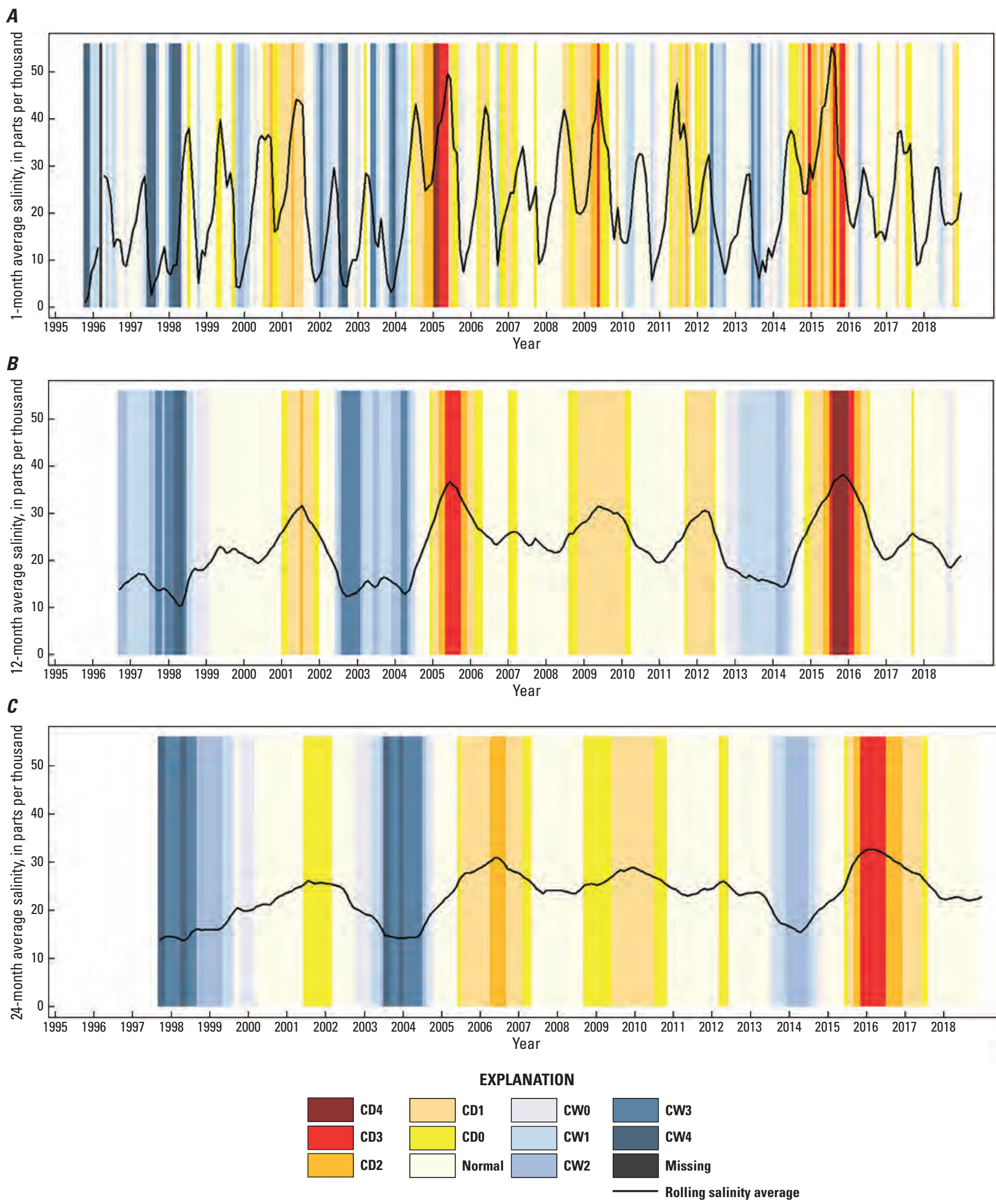

Figure 3. A, 1-month, B, 12-month, and C, 24-month Coastal Salinity Index computations for McCormick Creek at mouth near Key Largo, Florida (U.S. Geological Survey station 251003080435500), for the period October 1995 to December 2018. CD, coastal drought; CW, coastal wet. 
includes a monthly color band as fill in the background representing the CSI coastal drought classes (CD0 to CD4; yellow-red color ramp), coastal freshwater classes (CW0 to CW4; blue color ramp), and normal conditions. The color bands help the reader quickly identify the months with salinity conditions that are higher (drought conditions) or lower (wet conditions) than normal for that particular month. The red bands indicate drought conditions (for example, in 2005, 2009, 2014, and 2015), whereas the dark blue bands indicate wet conditions (for example in 1995, 1997, and 1998, among others). To evaluate medium- and long-term coastal salinity conditions, one can review the 12- or 24-month CSI intervals (fig. $3 B$ and $3 C$, respectively). Drought or wet conditions may not be evident in the CSI graphs depending on the length of the CSI interval selected. For example, a CSI class of CD3 is observed in 2005 for a CSI interval of 12 months (fig. $3 B$ ) but not for a CSI interval of 24 months (fig. $3 C$ ).

Plotting stacked CSI results-The CSIstack function produces graphs showing the 1-month to 24-month CSI interval calculations on the same graph (fig. 4). Short- to long-term conditions can be shown on one graph by calculating the CSI values for all time intervals between 1 and 24 months and "stacking" the coastal drought and freshwater color classes. The computed stacked CSI graph for McCormick Creek near Key Largo, Fla. (USGS station 251003080435500), is shown as an example in figure 4 . The CSI interval is listed on the primary $y$-axis from 1 month at the origin and 24 months at the top of the y-axis. The 12-month moving average salinity value is displayed using the secondary $y$-axis and depicted as a blue line on the graph. The secondary y-axis also displays the associated estuarine salinity ranges (oligohaline, mesohaline, polyhaline, euhaline, and hyperhaline) in practical salinity units. By showing 24 CSI intervals on one graph, the short- to long-term magnitude, duration, onset, and recovery of coastal salinity and freshwater conditions can be evaluated. Additional graphs can be created showing cumulative percentages, the distribution of values in histogram format, and the above- and below-normal CSI values for the period of record. Salinity duration hydrographs that overlay the current salinity values on the monthly historical range of the salinity data also can be created. Detailed descriptions of these and other CSI functions are available in the $\mathrm{R}$ package help pages and in the User Guide (appendix 1).
Exporting CSI results-With the CSIwrite function, CSI values are written to comma-separated values (.csv) text files, one file per gage, providing monthly CSI values for each month in the record for 1- to 24-month intervals (fig. 5). This main output file consists of months listed as row headers, CSI intervals listed as column headers, and CSI results listed at the intersection of the individual months and CSI intervals (fig. 5). Another output file contains the final mean monthly salinity data used to calculate CSI values, including possible converted and (or) interpolated values. An additional text file is produced with statistics about the stations, including the minimum, maximum, median, first and third quartile values, date ranges, and number of missing months. If the R package produces interpolated data, another output file details each of the gaps filled for each input gage.

\section{Computation of the Coastal Salinity Index for Locations in the South Atlantic and Gulf of Mexico}

The computation of the CSI at monitoring sites along the coast was a critical step in this investigation. This task was necessary to provide the data and information to increase opportunities for users to link the CSI to ecological response data.

\section{Site Selection}

The site-selection sub-task sought to identify the availability of salinity data for CSI calculations by examining the various monitoring networks along the southeastern Atlantic coast and the Gulf of Mexico. The initial search focused on identifying water-quality datasets for coastal locations in the Southeastern and Southern United States (from North Carolina to Texas) and available through the USGS NWIS and the NOAA NERRS SWMP. Both USGS and the SWMP regularly collect and maintain long-term water-quality data. Potential CSI sites were identified within the USGS Southeast Region, including sites maintained by the Lower Mississippi Gulf, Caribbean-Florida, and South Atlantic Water Science Centers. The sites included historical, active, and real-time monitoring sites. Eleven NERRS programs are within the geographic scope of this project. Each NERRS program maintains three or four salinity monitoring sites, one of which provides real-time data.

Because the SPI served as the model for the development of the CSI, sites were selected on the basis of criteria 

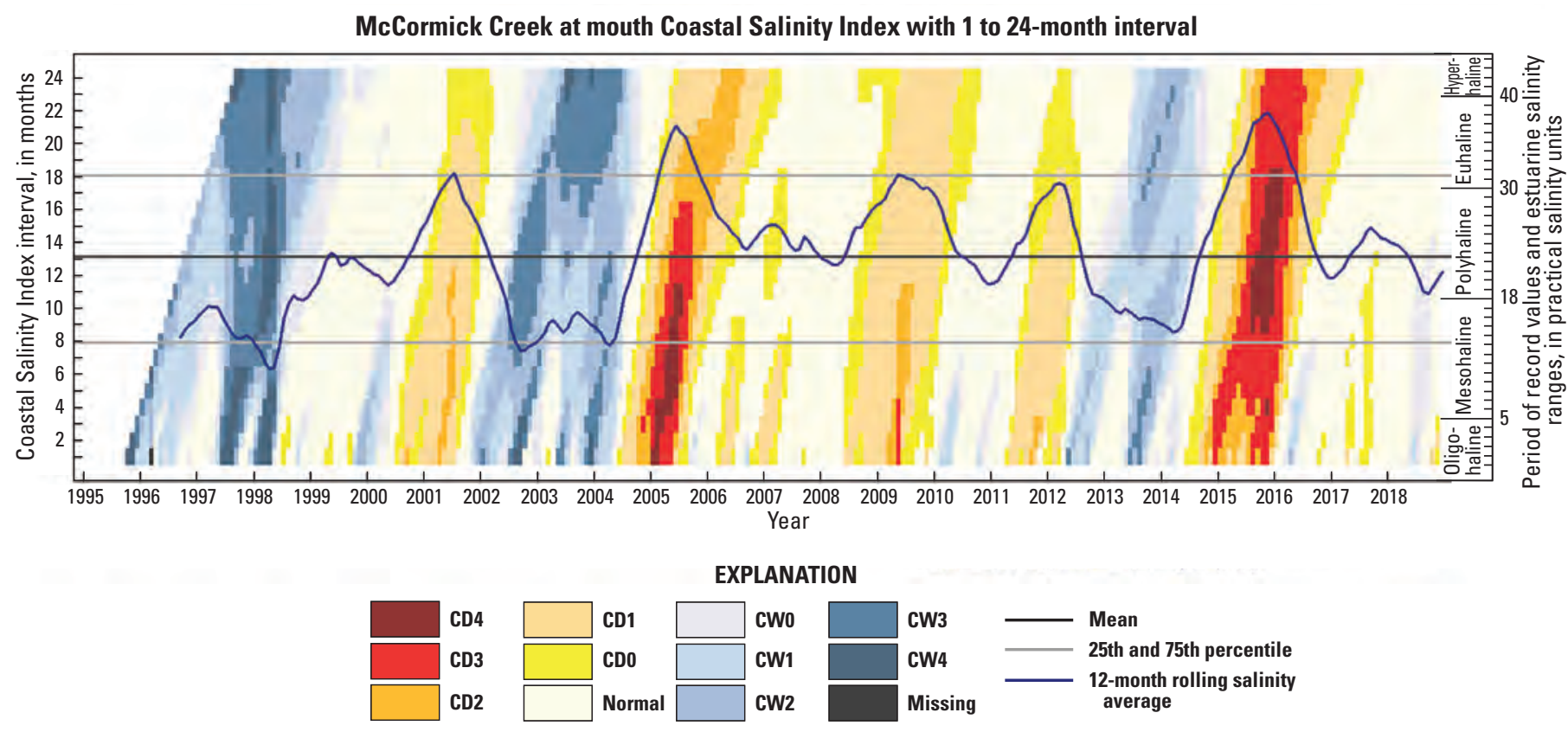

Figure 4. Stacked Coastal Salinity Index computations for McCormick Creek at mouth near Key Largo, Florida (U.S. Geological Survey station 251003080435500), for the period October 1995 to December 2018. CD, coastal drought; CW, coastal wet.

\begin{tabular}{c|c|c|c|c|c|c} 
& 1 & 2 & 3 & 4 & 5 & 6 \\
\hline $1995-10$ & 2.569214 & NA & NA & NA & NA & NA \\
\hline $1995-11$ & 2.219577 & 2.448567 & NA & NA & NA & NA \\
\hline $1995-12$ & 1.172532 & 1.680216 & 1.952599 & NA & NA & NA \\
\hline $1996-1$ & 1.259778 & 1.237956 & 1.575649 & 1.785221 & NA & NA \\
\hline $1996-2$ & 1.20434 & 1.252561 & 1.260916 & 1.53169 & 1.704055 & NA \\
\hline $1996-3$ & 1.163585 & 1.200401 & 1.242993 & 1.269426 & 1.506455 & 1.659507 \\
\hline $1996-4$ & 0.411373 & 0.82555 & 0.9531 & 1.038833 & 1.09933 & 1.321848 \\
\hline $1996-5$ & 1.033791 & 0.811588 & 1.018042 & 1.094376 & 1.148156 & 1.190912 \\
\hline $1996-6$ & 0.613757 & 0.852317 & 0.833624 & 1.043622 & 1.142544 & 1.202319 \\
\hline $1996-7$ & 0.961666 & 0.82902 & 0.976013 & 0.976352 & 1.153241 & 1.251661 \\
\hline $1996-8$ & 0.726291 & 0.882279 & 0.83226 & 0.956915 & 0.969774 & 1.122928 \\
\hline $1996-9$ & 0.355157 & 0.604189 & 0.78494 & 0.780193 & 0.892493 & 0.914364 \\
\hline $1996-10$ & 0.238559 & 0.490118 & 0.670974 & 0.8269 & 0.809572 & 0.900969 \\
\hline $1996-11$ & 0.575924 & 0.429582 & 0.660661 & 0.798663 & 0.925297 & 0.890279 \\
\hline $1996-12$ & 0.256799 & 0.448799 & 0.405536 & 0.594239 & 0.74952 & 0.888027 \\
\hline
\end{tabular}

Figure 5. An example Coastal Salinity Index (CSI) R package output file, with CSI intervals as column headers and individual months as rows. 
recommended for SPI calculations (World Meteorological Organization, 2012; World Meteorological Organization and Global Water Partnership, 2016). Ideally, the dataset used to calculate the CSI should be as complete as possible, consist of regularly collected data, and comprise a minimum of 30 years of data to account for occurrences of extreme wet and extreme dry periods. A physical location with no hydraulic barriers to saline waters at the gaging station was another consideration. At the start, there were over 100 real-time sites with a minimum of 10 years of data and 50 real-time sites with at least 18 years of salinity data. Because of the limited number of complete, long-term salinity datasets in the study area, the list of potential CSI sites was limited to the stations with 18 or more years of data. USGS researchers working on RESTORErelated projects also reviewed the list of 50 sites for applicability to their ongoing investigations. They identified 25 sites of interest between Texas and Tampa, Fla.

After reviewing the USGS and NERRS datasets, CISA searched for additional sites where salinity data are available and where CSI calculations could be useful for DEWS activities in the South Atlantic (North Carolina, South Carolina, Georgia) and Gulf Coast. Examples include federally supported monitoring efforts of the NPS, the Southeast Coastal Ocean Observing Regional Association, the Defense Coastal/ Estuarine Research Program based at Marine Corps Base Camp Lejeune (North Carolina), and the Georgia Coastal Ecosystems Long Term Ecological Research Network. Monitoring efforts conducted by State and local agencies, nonprofit organizations, and academic research groups were also identified and considered. Examples include the South Carolina Department of Natural Resources, University of North Carolina Wilmington Coastal Ocean Research Monitoring Program, North Carolina State University Center for Applied Aquatic Ecology, Long Bay Hypoxia Monitoring Consortium (South Carolina), and Lower Colorado River Authority (Texas). Many of the datasets identified through this search were associated with specific research projects that were either time or funding limited. CISA identified 47 additional sites for CSI calculation. Some sites with less than 18 years of data were selected because of interest from DEWS researchers and stakeholders.

Ultimately, 97 sites within the study area were selected for CSI calculation (fig. 6; table 2). These sites are in the coastal rivers, bays, estuaries, and sounds of North and South Carolina, Georgia, Florida, Alabama, Mississippi, Louisiana, Texas, and Puerto Rico. Historic CSIs were calculated using the available data at each site. The period of record varied for each site, with 1983 being the earliest recorded salinity and September 2018 being chosen for the ending month (when available) for these calculations. Some sites were discontinued prior to September 2018. Figure 6 shows where real-time CSI calculations are available for 12 southern Florida sites and 17 South Atlantic sites. Metadata compiled for the selected CSI sites included monitoring agency, site location, dates of data collection, and the online repository where the CSI results will be stored (table 2).

\section{ScienceBase Dissemination}

After the salinity data were processed through the CSI R package, they required systematic archiving and dissemination. As CSIs are computed, it is important that the values are provided to researchers and the public in an accessible and citable format. To enhance and expand information sharing and sound data management practices, the USGS developed ScienceBase - a collaborative scientific data and information management platform used directly by science teams (https:// www.sciencebase.gov/about/). All USGS ScienceBase data releases go through a detailed review process for quality assurance of the validity of the data and data release format. A citable Digital Object Identifier is provided for each USGS data release.

The historic CSI results for this investigation are archived in ScienceBase for current and future use by interested researchers (Petkewich and others, 2019; https://doi. org/10.5066/P9MQLNL2). The landing page for the data release presents a general description of the CSI and the associated metadata; it also contains files describing the structure of the data release, the tables included, and a list of sites where the CSI has been calculated. The landing page contains multiple folders identifying the States where the CSIs have been calculated. Each State folder consists of one to many zipped folders with the data used to calculate each CSI and the input and output files associated with each CSI calculation. Future CSI results can be added to this data release after detailed quality-assurance review of the new data.

\section{Computation and Dissemination of Real-time Coastal Salinity Index Results}

The availability of telemetered real-time salinity data allows the USGS to present real-time coastal drought conditions to the community of climatologists and coastal resource managers such as marine fisheries managers, water utilities, and refuge managers. The framework developed for the computation and dissemination of real-time CSIs includes documenting metadata, estimating periods of missing data, and archiving results. The real-time computation of the CSI integrates computer scripts to (1) acquire real-time salinity and (or) specific conductance data from the USGS NWIS, (2) load processed salinity data into a local database, (3) compute CSIs for 1- to 24-month scales, and (4) create visualization products and distribute results to USGS websites. Real-time CSI results are available on two USGS websites. 


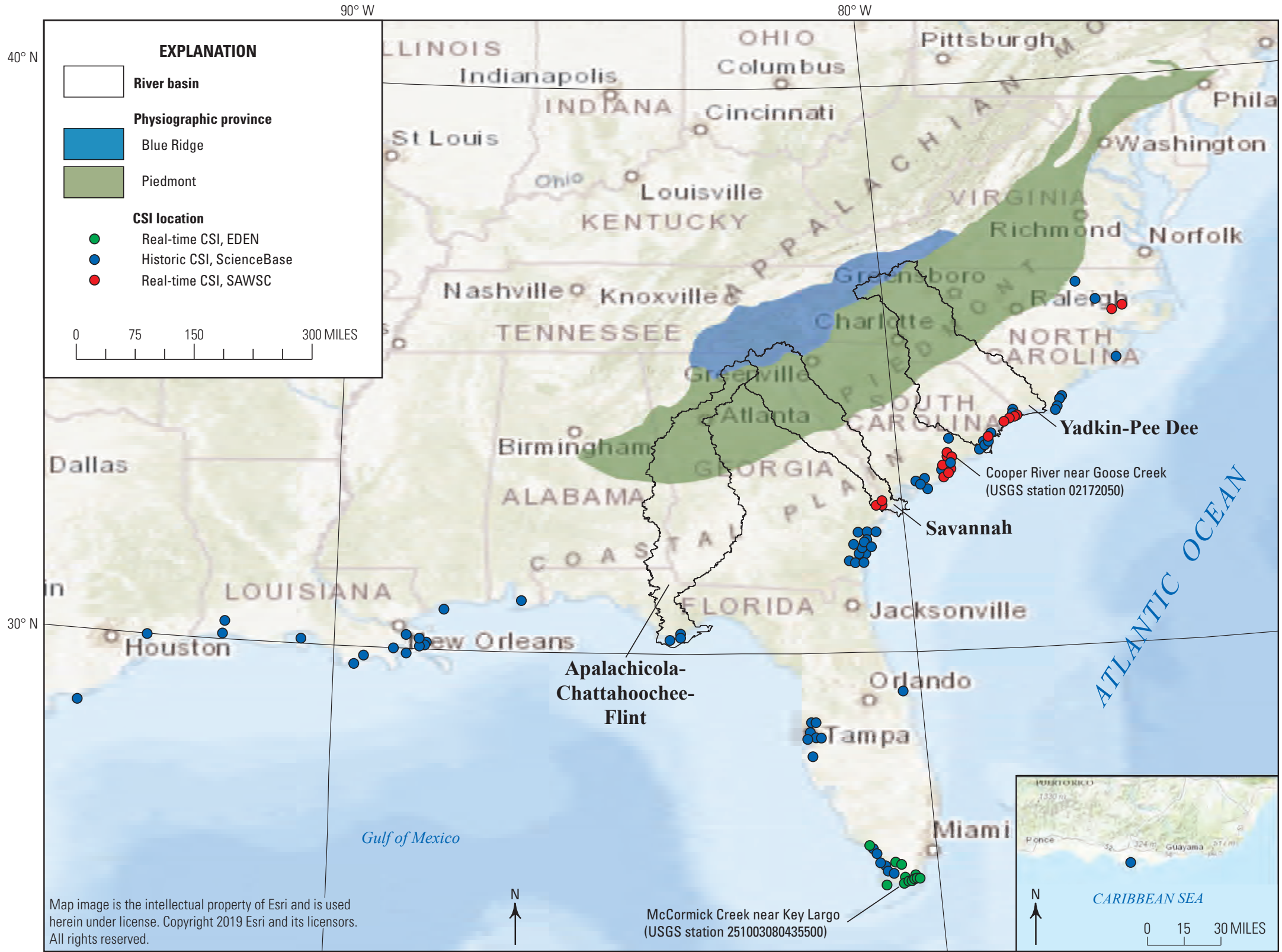

Figure 6. Locations of the water-quality sites used in the Coastal Salinity Index (CSI) calculations. EDEN, Everglades Depth Estimation Network; SAWSC, South Atlantic Water Science Center; USGS, U.S. Geological Survey. 
Table 2. Station numbers, station names, dates, and locations of sites used in the Coastal Salinity Index (CSI) calculations.

[NERRS, National Estuarine Research Reserve System; AL, Alabama; FL, Florida; USGS, U.S. Geological Survey; EDEN, Everglades Depth Estimation Network; Pk, Park; Dr, Drive; GCE LTER, Georgia Coastal Ecosystems Long Term Ecological Research; GA, Georgia; LA, Louisiana; MS, Mississippi; NC, North Carolina; PR, Puerto Rico; SC, South Carolina; SAWSC, South Atlantic Water Science Center; HWY, Highway; LCRA, Lower Colorado River Authority; TX, Texas, Rv, River]

\begin{tabular}{|c|c|c|c|c|c|c|c|}
\hline Station name & $\begin{array}{c}\text { Station } \\
\text { identification }\end{array}$ & Agency' & Begin date & End date & Latitude & Longitude & CSI location \\
\hline \multicolumn{8}{|c|}{ Alabama } \\
\hline Fish River & WKBFRWQ & NERRS & $10 / 27 / 1995$ & $9 / 30 / 2018$ & 30.41620 & -87.82280 & ScienceBase \\
\hline \multicolumn{8}{|c|}{ Florida } \\
\hline Cat Point & APACPWQ & NERRS & $1 / 1 / 2002$ & $9 / 30 / 2018$ & 29.70210 & -84.88020 & ScienceBase \\
\hline Dry Bar & APADBWQ & NERRS & $1 / 1 / 2002$ & $9 / 30 / 2018$ & 29.67470 & -85.05830 & ScienceBase \\
\hline East Bay Bottom & APAEBWQ & NERRS & $5 / 1 / 1995$ & $9 / 30 / 2018$ & 29.78580 & -84.87520 & ScienceBase \\
\hline East Side Creek near Lake Ingraham & 250802081035500 & USGS & $2 / 20 / 2009$ & $9 / 30 / 2018$ & 25.13696944 & -81.0643806 & EDEN \\
\hline McCormick Creek at mouth, near Key Largo & 251003080435500 & USGS & $10 / 28 / 1995$ & $9 / 30 / 2018$ & 25.16859547 & -80.7333764 & EDEN \\
\hline Taylor River at mouth, near Homestead & 251127080382100 & USGS & $10 / 26 / 1995$ & 9/30/2018 & 25.1909944 & -80.6388378 & EDEN \\
\hline Mud Creek at mouth, near Homestead & 251209080350100 & USGS & $10 / 27 / 1995$ & 9/30/2018 & 25.2037021 & -80.5838946 & EDEN \\
\hline Upstream Taylor River near Homestead, FL & 251241080385300 & USGS & $7 / 31 / 1999$ & 9/30/2018 & 25.2102972 & -80.6476667 & EDEN \\
\hline Trout Creek at mouth, near Key Largo & 251253080320100 & USGS & $1 / 21 / 1996$ & 9/30/2018 & 25.21530426 & -80.5332849 & EDEN \\
\hline Joe Bay 2E, near Key Largo & 251355080312800 & USGS & $5 / 27 / 1999$ & $9 / 30 / 2018$ & 25.232625 & -80.5248667 & EDEN \\
\hline West Highway Creek, near Homestead & 251433080265000 & USGS & 2/8/1996 & $9 / 30 / 2018$ & 25.24210833 & -80.4475722 & EDEN \\
\hline G-3777 & 251457080395802 & USGS & $10 / 5 / 2003$ & $9 / 30 / 2018$ & 25.25255556 & -80.6662611 & EDEN \\
\hline EDEN_3 In Everglades National Park & 253044080555900 & USGS & $11 / 10 / 2005$ & 9/30/2018 & 25.512125 & -80.9331528 & EDEN \\
\hline Bottle Creek at Rookery Branch near Homestead, FL & 022908295 & USGS & $10 / 27 / 2003$ & 9/30/2018 & 25.46797778 & -80.8545278 & EDEN \\
\hline Barron River at Everglades City, FL & 02290928 & USGS & $9 / 12 / 2001$ & 9/30/2018 & 25.8697222 & -81.3825 & EDEN \\
\hline Shark River Below Gunboat Island & 252230081021300 & USGS & $3 / 16 / 2001$ & ${ }^{2} 12 / 15 / 2014$ & 25.3753255 & -81.036493 & ScienceBase \\
\hline Haulover Canal near Mims, FL & 02248380 & USGS & $4 / 8 / 1998$ & $29 / 29 / 2016$ & 28.73638079 & -80.754773 & ScienceBase \\
\hline North River Upstream of Cutoff & 022908205 & USGS & $3 / 16 / 2001$ & ${ }^{2} 12 / 17 / 2014$ & 25.33900677 & -80.9131256 & ScienceBase \\
\hline Broad River near the cutoff & 02290878 & USGS & $2 / 23 / 2001$ & ${ }^{2} 1 / 21 / 2015$ & 25.50138889 & -81.0769444 & ScienceBase \\
\hline Chatham River near the Watson Place & 02290888 & USGS & $3 / 29 / 2001$ & ${ }^{2} 1 / 20 / 2015$ & 25.70916667 & -81.2497222 & ScienceBase \\
\hline Lostmans River below Second Bay & 02290918 & USGS & $3 / 27 / 2001$ & ${ }^{2} 1 / 21 / 2015$ & 25.55555556 & -81.1647222 & ScienceBase \\
\hline Lopez River & 02290942 & USGS & $4 / 19 / 2001$ & ${ }^{2} 1 / 20 / 2015$ & 25.79138889 & -81.2997222 & ScienceBase \\
\hline Manatee River at Fort Hamer FL & 02300021 & USGS & ${ }^{3} 1 / 25 / 2001$ & ${ }^{2} 10 / 13 / 2016$ & 27.51837203 & -82.4281499 & ScienceBase \\
\hline Alafia River at Bell Shoals near Riverview FL & 02301638 & USGS & $4 / 18 / 1998$ & $9 / 30 / 2018$ & 27.85891477 & -82.2737021 & ScienceBase \\
\hline Alafia River at Riverview FL & 02301718 & USGS & $5 / 14 / 1999$ & $9 / 30 / 2018$ & 27.86780308 & -82.3198141 & ScienceBase \\
\hline Alafia River at Gibsonton FL & 02301721 & USGS & $5 / 10 / 1999$ & $9 / 30 / 2018$ & 27.85974739 & -82.3842598 & ScienceBase \\
\hline Hillsborough River at Rowlett Pk Dr near Tampa FL & 02304510 & USGS & $12 / 24 / 1996$ & $9 / 30 / 2018$ & 28.02113015 & -82.4345385 & ScienceBase \\
\hline Sulphur Springs at Sulphur Springs FL & 02306000 & USGS & 5/23/1999 & $9 / 30 / 2018$ & 28.02113004 & -82.451761 & ScienceBase \\
\hline Hillsborough River at Platt Street at Tampa FL & 02306028 & USGS & ${ }^{3} 2 / 17 / 2001$ & $9 / 30 / 2018$ & 27.94196627 & -82.4587057 & ScienceBase \\
\hline
\end{tabular}


Table 2. Station numbers, station names, dates, and locations of sites used in the Coastal Salinity Index (CSI) calculations.-Continued

[NERRS, National Estuarine Research Reserve System; AL, Alabama; FL, Florida; USGS, U.S. Geological Survey; EDEN, Everglades Depth Estimation Network; Pk, Park; Dr, Drive; GCE LTER, Georgia Coastal Ecosystems Long Term Ecological Research; GA, Georgia; LA, Louisiana; MS, Mississippi; NC, North Carolina; PR, Puerto Rico; SC, South Carolina; SAWSC, South Atlantic Water Science Center; HWY, Highway; LCRA, Lower Colorado River Authority; TX, Texas, Rv, River]

\begin{tabular}{|c|c|c|c|c|c|c|c|}
\hline Station name & $\begin{array}{c}\text { Station } \\
\text { identification }\end{array}$ & Agency $^{1}$ & Begin date & End date & Latitude & Longitude & CSI location \\
\hline \multicolumn{8}{|c|}{ Georgia } \\
\hline Sapelo River near Eulonia & GCE LTER 1 & GCE LTER & $9 / 13 / 2001$ & $9 / 30 / 2018$ & 31.53748333 & -81.42398333 & ScienceBase \\
\hline Sapelo River near Four Mile Island & GCE LTER 2 & GCE LTER & $10 / 26 / 2001$ & $9 / 30 / 2018$ & 31.544957 & -81.319934 & ScienceBase \\
\hline Sapelo Sound near North Sapelo & GCE LTER 3 & GCE LTER & $8 / 8 / 2001$ & $9 / 30 / 2018$ & 31.548264 & -81.210833 & ScienceBase \\
\hline Hudson Creek & GCE LTER 4 & GCE LTER & $2 / 3 / 2001$ & $9 / 30 / 2018$ & 31.453559 & -81.362743 & ScienceBase \\
\hline Doboy Sound near Commodore Island & GCE LTER 6 & GCE LTER & $2 / 25 / 2002$ & $9 / 30 / 2018$ & 31.39345901 & -81.30492173 & ScienceBase \\
\hline Altamaha River near Carrs Island & GCE LTER 7 & GCE LTER & $8 / 10 / 2001$ & $9 / 30 / 2018$ & 31.33819 & -81.475477 & ScienceBase \\
\hline Altamaha River near Alligator Creek & GCE LTER 8 & GCE LTER & $10 / 26 / 2001$ & $9 / 30 / 2018$ & 31.310279 & -81.410051 & ScienceBase \\
\hline Altamaha River near Rockdedundy Island & GCE LTER 9 & GCE LTER & $2 / 25 / 2002$ & $9 / 30 / 2018$ & 31.320099 & -81.321964 & ScienceBase \\
\hline Duplin River at Flume Dock & GCE LTER 10 & GCE LTER & $7 / 17 / 2003$ & $9 / 30 / 2018$ & 31.48248333 & -81.26791667 & ScienceBase \\
\hline Cabretta Creek & SAPCAWQ & NERRS & $8 / 30 / 2004$ & $9 / 30 / 2018$ & 31.44370 & -81.23990 & ScienceBase \\
\hline Dean Creek & SAPDCWQ & NERRS & $5 / 1 / 2004$ & $9 / 30 / 2018$ & 31.38960 & -81.27890 & ScienceBase \\
\hline Hunt Dock & SAPHDWQ & NERRS & 7/3/1999 & $9 / 30 / 2018$ & 31.47860 & -81.27310 & ScienceBase \\
\hline Lower Duplin & SAPLDWQ & NERRS & $1 / 1 / 1999$ & $9 / 30 / 2018$ & 31.41794 & -81.29605 & ScienceBase \\
\hline Savannah River at GA 25, at Port Wentworth, GA & 02198920 & USGS & $10 / 1 / 1987$ & $9 / 30 / 2018$ & 32.1660358 & -81.1537237 & SAWSC \\
\hline \multicolumn{8}{|c|}{ Louisiana } \\
\hline Reggio Canal near Wills Point, LA & 073745253 & USGS & $1 / 27 / 1999$ & $9 / 30 / 2018$ & 29.78416667 & -89.9375 & ScienceBase \\
\hline Crooked B. NW of L. Cuatro Caballo near Delacroix & 073745257 & USGS & 9/30/1998 & $9 / 30 / 2018$ & 29.7082661 & -89.7195065 & ScienceBase \\
\hline Cow Bayou at American Bay nr Pointe-A-La-Hache, LA & 073745258 & USGS & $1 / 28 / 1999$ & $9 / 30 / 2018$ & 29.57076989 & -89.7039524 & ScienceBase \\
\hline Black Bay nr Snake Island nr Pointe-A-La-Hache, LA & 07374526 & USGS & 9/30/1994 & $9 / 30 / 2018$ & 29.63354395 & -89.5636694 & ScienceBase \\
\hline Northeast Bay Gardene near Point-A-LA-Hache, LA & 07374527 & USGS & 9/30/1994 & $9 / 30 / 2018$ & 29.5859626 & -89.6060323 & ScienceBase \\
\hline Barataria Bay $\mathrm{N}$ of Grand Isle, LA & 07380251 & USGS & $3 / 14 / 1996$ & $9 / 30 / 2018$ & 29.42272045 & -89.9506268 & ScienceBase \\
\hline Little Lake Near Cutoff, LA & 07380335 & USGS & 10/1/1996 & $9 / 30 / 2018$ & 29.5177174 & -90.1814655 & ScienceBase \\
\hline Houma Navigation Canal at Dulac, LA & 07381328 & USGS & $39 / 30 / 1993$ & $9 / 30 / 2018$ & 29.38522075 & -90.729812 & ScienceBase \\
\hline Caillou Lake (Sister Lake) SW of Dulac, LA & 07381349 & USGS & $5 / 22 / 1997$ & $9 / 30 / 2018$ & 29.24916667 & -90.9211111 & ScienceBase \\
\hline Vermilion Bay near Cypremort Point, LA & 07387040 & USGS & ${ }^{3} 10 / 1 / 1998$ & $9 / 30 / 2018$ & 29.71326575 & -91.8803982 & ScienceBase \\
\hline North Calcasieu Lake near Hackberry, LA & 08017095 & USGS & $7 / 25 / 1997$ & $9 / 30 / 2018$ & 30.0318786 & -93.2995989 & ScienceBase \\
\hline Calcasieu River at Cameron, LA & 08017118 & USGS & $10 / 22 / 1998$ & $9 / 30 / 2018$ & 29.8157762 & -93.349043 & ScienceBase \\
\hline \multicolumn{8}{|c|}{ Mississippi } \\
\hline Mississippi Sound at USGS Merrill Shell Bank Light & 301429089145600 & USGS & 9/6/1998 & 9/30/2018 & 30.23825405 & -89.24281939 & ScienceBase \\
\hline
\end{tabular}


Table 2. Station numbers, station names, dates, and locations of sites used in the Coastal Salinity Index (CSI) calculations.-Continued

[NERRS, National Estuarine Research Reserve System; AL, Alabama; FL, Florida; USGS, U.S. Geological Survey; EDEN, Everglades Depth Estimation Network; Pk, Park; Dr, Drive; GCE LTER, Georgia Coastal Ecosystems Long Term Ecological Research; GA, Georgia; LA, Louisiana; MS, Mississippi; NC, North Carolina; PR, Puerto Rico; SC, South Carolina; SAWSC, South Atlantic Water Science Center; HWY, Highway; LCRA, Lower Colorado River Authority; TX, Texas, Rv, River]

\begin{tabular}{|c|c|c|c|c|c|c|c|}
\hline Station name & $\begin{array}{c}\text { Station } \\
\text { identification }\end{array}$ & Agency $^{1}$ & Begin date & End date & Latitude & Longitude & CSI location \\
\hline \multicolumn{8}{|c|}{ North Carolina } \\
\hline East Cribbing & NOCECWQ & NERRS & $5 / 19 / 1994$ & 9/30/2018 & 33.93990 & -77.94110 & ScienceBase \\
\hline Loosin Creek & NOCLCWQ & NERRS & $2 / 26 / 2002$ & 9/30/2018 & 34.17220 & -77.83280 & ScienceBase \\
\hline Research Creek & NOCRCWQ & NERRS & $5 / 1 / 1994$ & 9/30/2018 & 34.15600 & -77.84990 & ScienceBase \\
\hline Zeke's Basin & NOCZBWQ & NERRS & $3 / 1 / 2002$ & 9/30/2018 & 33.95470 & -77.93500 & ScienceBase \\
\hline Roanoke River at Halifax, NC & 0208062765 & USGS & $3 / 14 / 1998$ & $9 / 30 / 2018$ & 36.3311111 & -77.58027778 & ScienceBase \\
\hline Roanoke River near Oak City, NC & 02081022 & USGS & $3 / 18 / 1998$ & 9/30/2018 & 36.0136111 & -77.21527778 & ScienceBase \\
\hline Roanoke River at Jamesville, NC & 02081094 & USGS & $3 / 4 / 1998$ & 9/30/2018 & 35.81305556 & -76.89277778 & SAWSC \\
\hline Roanoke River at NC 45 near Westover, NC & 0208114150 & USGS & $11 / 26 / 1997$ & $9 / 30 / 2018$ & 35.915 & -76.72277778 & SAWSC \\
\hline Neuse River at Channel Light 9 at Cherry Point, NC & 0209265810 & USGS & $5 / 31 / 1989$ & ${ }^{2} 6 / 2 / 2009$ & 34.9486111 & -76.8097222 & ScienceBase \\
\hline \multicolumn{8}{|c|}{ Puerto Rico } \\
\hline Station 9 & JOB09WQ & NERRS & $12 / 20 / 1995$ & $9 / 30 / 2018$ & 17.94306 & -66.23858 & ScienceBase \\
\hline \multicolumn{8}{|c|}{ South Carolina } \\
\hline Big Bay & ACEBBWQ & NERRS & $3 / 3 / 1995$ & ${ }^{2} 1 / 7 / 2015$ & 32.49410 & -80.32410 & ScienceBase \\
\hline Fishing Creek & ACEFCWQ & NERRS & $10 / 16 / 2002$ & $9 / 30 / 2018$ & 32.63593 & -80.36556 & ScienceBase \\
\hline Mosquito Creek & ACEMCWQ & NERRS & $10 / 15 / 2002$ & 9/30/2018 & 32.55580 & -80.43800 & ScienceBase \\
\hline St. Pierre & ACESPWQ & NERRS & $3 / 3 / 1995$ & 9/30/2018 & 32.52800 & -80.36144 & ScienceBase \\
\hline Clambank & NIWCBWQ & NERRS & $8 / 17 / 2001$ & 9/30/2018 & 33.33386 & -79.19304 & ScienceBase \\
\hline Debidue Creek & NIWDCWQ & NERRS & $3 / 5 / 1998$ & $9 / 30 / 2018$ & 33.36015 & -79.16746 & ScienceBase \\
\hline Oyster Landing & NIWOLWQ & NERRS & 1/1/1996 & $9 / 30 / 2018$ & 33.34935 & -79.18888 & ScienceBase \\
\hline Thousand Acre & NIWTAWQ & NERRS & $1 / 1 / 1995$ & 9/30/2018 & 33.29915 & -79.25606 & ScienceBase \\
\hline AIW at Briarcliffe Acres at N. Myrtle Beach, SC & 02110755 & USGS & $10 / 1 / 1983$ & $9 / 30 / 2018$ & 33.7985057 & -78.75307469 & SAWSC \\
\hline AIW@Myrtlewood Golf Course @ Myrtle Beach, SC & 02110760 & USGS & ${ }^{3} 2 / 19 / 1994$ & $9 / 30 / 2018$ & 33.74072759 & -78.8666928 & SAWSC \\
\hline AIW at Grand Strand Airport N. Myrtle Beach, SC & 02110770 & USGS & $4 / 16 / 1987$ & $9 / 30 / 2018$ & 33.82128347 & -78.7186287 & SAWSC \\
\hline AIW at Highway 9 at Nixons Crossroads, SC & 02110777 & USGS & $4 / 14 / 1986$ & $9 / 30 / 2018$ & 33.8515612 & -78.6558483 & SAWSC \\
\hline Waccamaw River near Hagley Landing near Pawleys Island, SC & 02110815 & USGS & $5 / 1 / 1986$ & $9 / 30 / 2018$ & 33.44461245 & -79.1739341 & SAWSC \\
\hline W Branch Cooper R@ Pimliconr Moncks Corner, SC & 02172020 & USGS & $4 / 27 / 1983$ & $9 / 30 / 2018$ & 33.0935042 & -79.9489708 & SAWSC \\
\hline Back River at Dupont Intake nr Kittredge, SC & 02172040 & USGS & ${ }^{3} 7 / 1 / 1984$ & $9 / 30 / 2018$ & 33.06378245 & -79.957027 & SAWSC \\
\hline Cooper R nr Goose Creek, SC & 02172050 & USGS & $37 / 1 / 1984$ & $9 / 30 / 2018$ & 33.05767134 & -79.93619338 & SAWSC \\
\hline Cooper River@ Filbin Creek@ North Charleston, SC & 021720677 & USGS & $4 / 4 / 1997$ & $9 / 30 / 2018$ & 32.89045228 & -79.9628645 & SAWSC \\
\hline Wando River above Mt. Pleasant, SC & 021720698 & USGS & $7 / 25 / 1992$ & $9 / 30 / 2018$ & 32.8590638 & -79.8961963 & SAWSC \\
\hline Cooper River at U.S. HWY 17 at Charleston, SC & 021720709 & USGS & $4 / 11 / 1997$ & $9 / 30 / 2018$ & 32.80239835 & -79.9100869 & SAWSC \\
\hline
\end{tabular}


Table 2. Station numbers, station names, dates, and locations of sites used in the Coastal Salinity Index (CSI) calculations.-Continued

[NERRS, National Estuarine Research Reserve System; AL, Alabama; FL, Florida; USGS, U.S. Geological Survey; EDEN, Everglades Depth Estimation Network; Pk, Park; Dr, Drive; GCE LTER, Georgia Coastal Ecosystems Long Term Ecological Research; GA, Georgia; LA, Louisiana; MS, Mississippi; NC, North Carolina; PR, Puerto Rico; SC, South Carolina; SAWSC, South Atlantic Water Science Center; HWY, Highway; LCRA, Lower Colorado River Authority; TX, Texas, Rv, River]

\begin{tabular}{|c|c|c|c|c|c|c|c|}
\hline Station name & $\begin{array}{c}\text { Station } \\
\text { identification }\end{array}$ & Agency $^{1}$ & Begin date & End date & Latitude & Longitude & CSI location \\
\hline \multicolumn{8}{|c|}{ South Carolina-Continued } \\
\hline Cooper River at Customs House (AUX) at Charleston, SC & 021720710 & USGS & $10 / 30 / 1986$ & $9 / 30 / 2018$ & 32.7804544 & -79.923699 & SAWSC \\
\hline Little Back River above Lucknow Canal near Limehouse, SC & 021989784 & USGS & $5 / 18 / 1990$ & 9/30/2018 & 32.18575747 & -81.11789 & SAWSC \\
\hline Little Back River at F\&W Dock, near Limehouse, SC & 021989791 & USGS & 9/13/1989 & $9 / 30 / 2018$ & 32.1707582 & -81.1181677 & SAWSC \\
\hline Buck Creek Near Longs, SC & 02110400 & USGS & $10 / 1 / 2005$ & $9 / 30 / 2018$ & 33.953505 & -78.71973988 & ScienceBase \\
\hline Waccamaw River near Longs, SC & 02110500 & USGS & $4 / 27 / 2007$ & $9 / 30 / 2018$ & 33.9126719 & -78.7150175 & ScienceBase \\
\hline Waccamaw River near Pawleys Island, SC & 021108125 & USGS & $11 / 30 / 2001$ & 9/30/2018 & 33.50655724 & -79.1269867 & ScienceBase \\
\hline Rediversion Canal at Santee River near St. Stephen, SC & 02171645 & USGS & $11 / 17 / 2006$ & 9/30/2018 & 33.4275 & -79.915 & ScienceBase \\
\hline Cooper River at Mobay near North Charleston, SC & 02172053 & USGS & $9 / 30 / 1983$ & $9 / 30 / 2018$ & 32.9835058 & -79.9228612 & ScienceBase \\
\hline Ashley River near North Charleston, SC & 021720869 & USGS & $5 / 5 / 2005$ & 9/30/2018 & 32.8346201 & -80.0237014 & ScienceBase \\
\hline \multicolumn{8}{|c|}{ Texas } \\
\hline West Bay@ Tripod & 6990 & LCRA & $12 / 21 / 1992$ & 9/30/2018 & 28.596 & -96.04 & ScienceBase \\
\hline Trinity Rv at Wallisville, TX & 08067252 & USGS & 3/19/1999 & $9 / 30 / 2018$ & 29.8124434 & -94.7313087 & ScienceBase \\
\hline
\end{tabular}

${ }^{1}$ Salinity data can be downloaded from the following web pages: https://waterdata.usgs.gov/nwis/inventory/ (USGS), http://cdmo.baruch.sc.edu/dges/ (NERRS), http://gce-lter.marsci.uga.edu/portal/ (GCE LTER), and https://waterquality.lcra.org/ (LCRA).

${ }^{2}$ End date is equal to the last measurement date for stations that have been discontinued.

${ }^{3}$ Start date for calculated results chosen to eliminate long period of missing record. 
The first release of real-time CSIs was on the USGS Coastal EDEN website in December 2017 (https://sofia.usgs. gov/eden/coastal/). EDEN is an important provider of qualityassured datasets for the Everglades restoration community. In addition to water-level data used by EDEN to generate daily water-surface and water-depth maps (Telis, 2006; Patino and others, 2018), a network of Coastal EDEN gages provides stage, salinity, and temperature data for the oligohaline/mesohaline zone in the southern part of the Florida Everglades.
The website introduces Coastal EDEN and provides links to other areas of the EDEN website. The website provides a map interface of current conditions, 7-day average, and 7-day change of conditions of water-level, water temperature, and salinity data. Selection of icons on the map retrieves graphs of water level, water temperature, and salinity (fig. 7). The first graph displays 3 years of daily and 7-day average water-level data (fig. $7 A$ ). For evaluation of current and long-term salinity conditions, CSI and salinity

$\boldsymbol{A}$

Gage McCormick Creek at mouth

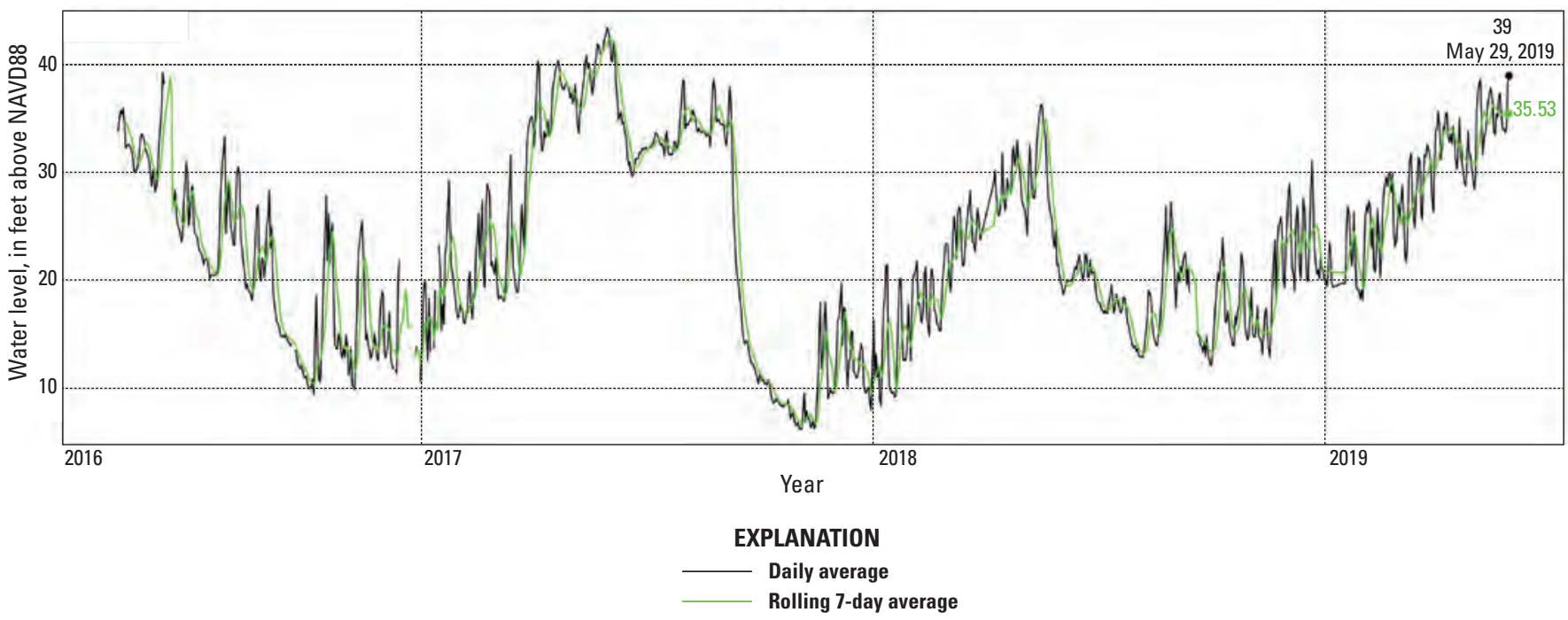

B McCormick Creek at mouth Coastal Salinity Index with 1- to 24-month interval
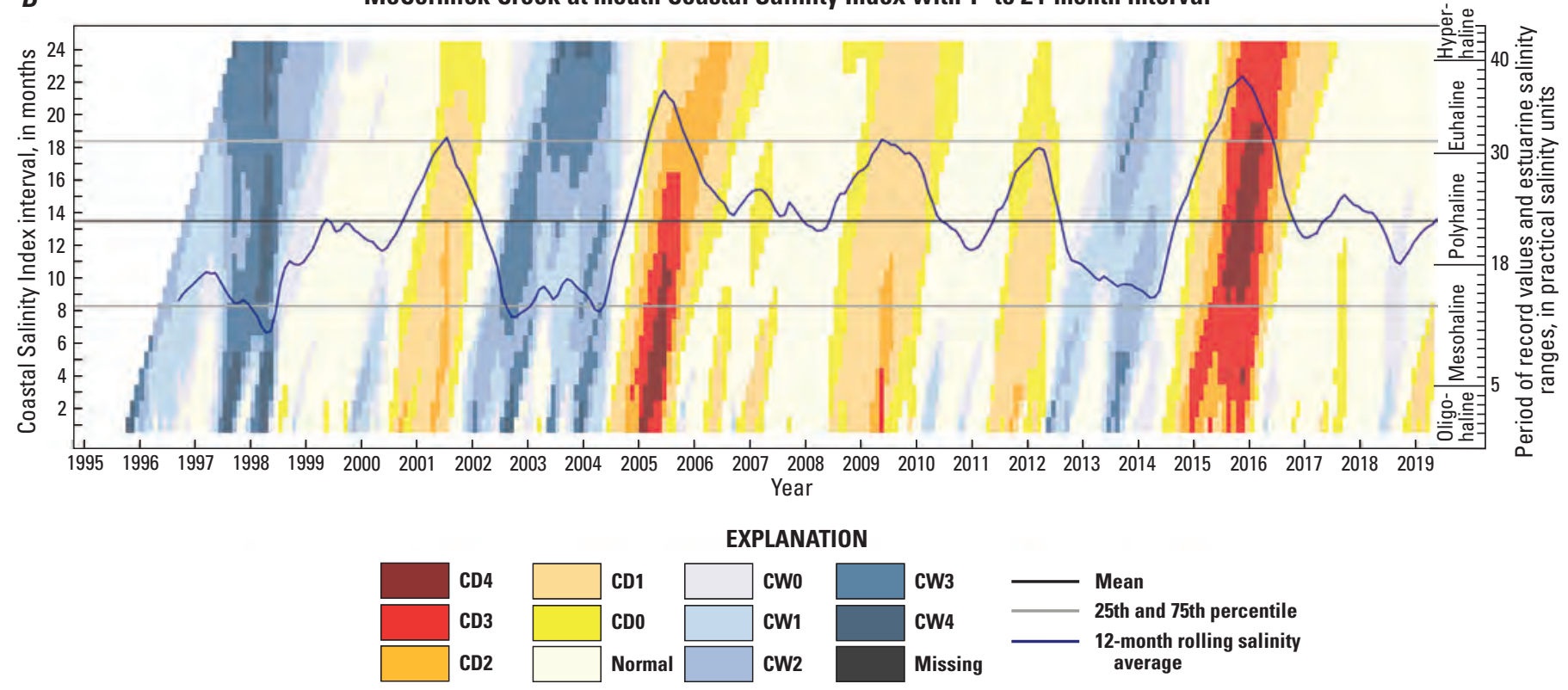

Figure 7. Graphs from the Coastal Everglades Depth Estimation Network web page showing real-time $A$, water elevation (stage), $B$, Coastal Salinity Index, and $C$, salinity duration for McCormick Creek at mouth near Key Largo, Florida (U.S. Geological Survey station 251003080435500). Max., maximum; Min., minimum; NAVD88, North American Vertical Datum of 1988. 
duration hydrographs are displayed (fig. $7 B$ and $7 C$, respectively). Short- to long-term salinity conditions are depicted on the CSI stacked graphs for 12 of the Coastal EDEN sites. Links are available to download all data used to calculate CSI values, in the same format provided by the CSI R package. To evaluate current salinity and temperature conditions relative to the ranges of historical salinity experienced at a site, salinity duration hydrographs (similar in concept to flow and waterlevel duration hydrographs) are generated and overlay the current salinity values on the monthly historical range of the salinity data (fig. $7 C$ ). Thus, one can quickly evaluate whether current conditions are fresher (less saline) or saltier (more saline) than normal. Current water temperature also is shown on these graphs.

A second website (https://www2.usgs.gov/water/southatlantic/projects/coastalsalinity/home.php) was created to disseminate CSI results for 17 sites where the real-time CSI has been computed for the South Atlantic Water Science Center. This website contains graphs that are similar to those on the Coastal EDEN website as described above.

C

McCormick Creek at mouth, 3-year salinity, 30-day moving window

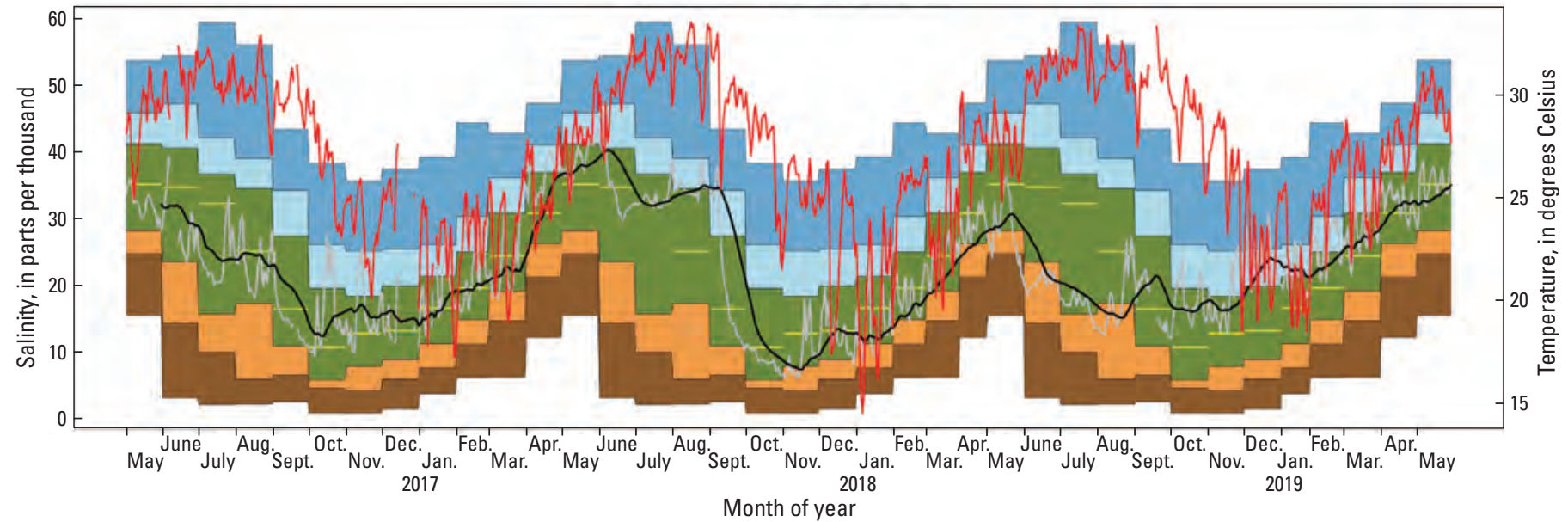

EXPLANATION

Salinity bin

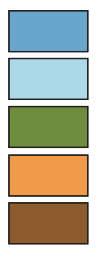

$90 \%$ to Max.

$75 \%$ to $90 \%$

$25 \%$ to $75 \%$

$10 \%$ to $25 \%$

Min. to $10 \%$

Salinity 30-day moving window

Daily salinity value

Daily temperature value

Historic monthly mean salinity

Figure 7. Graphs from the Coastal Everglades Depth Estimation Network web page showing real-time $A$, water elevation (stage), $B$, Coastal Salinity Index, and $C$, salinity duration for McCormick Creek at mouth near Key Largo, Florida (U.S. Geological Survey station 251003080435500). Max., maximum; Min., minimum; NAVD88, North American Vertical Datum of 1988.—Continued 


\section{Use and Interpretation of the Coastal Salinity Index}

As part of this project, CISA and the USGS established a CSI working group for the Carolinas with the goal of obtaining feedback on the CSI tool development and identifying opportunities to apply the CSI for drought and resource monitoring and management. Group members represented Federal and State agencies and nongovernmental organizations that had interests as potential data providers, CSI users, or both. Their input, and the process to complete the tasks described in this report, have revealed strengths and challenges associated with the calculation, use, and interpretation of the CSI.

\section{Data Considerations}

As with the SPI, one strength of the CSI is its flexibility. It is relatively simple to calculate, can be calculated for multiple time intervals, and shows wet as well as dry periods. The CSI R package can accommodate datasets of varying lengths and datasets with missing data.

Although this project prioritized regularly collected, continuous data from fixed sites, the R package can also accommodate data collected at less frequent or irregular intervals. For example, CSIs have been calculated for the Ashley River and Ashepoo, Combahee, and Edisto Basin areas using salinity data collected through South Carolina Department of Natural Resources (SCDNR) trammel net surveys that have taken place monthly since the early 1990s. The data are collected through a stratified random sampling method; each month, samples are collected at 10-12 sites selected from a pool of 22-30 sites (Arnott and others, 2010).

As the SCDNR example suggests, many existing salinity datasets could be potential candidates for CSI calculations. The "Standardized Precipitation Index User Guide" (World Meteorological Organization, 2012), however, recommends at least 20-30 years of monthly values, with longer datasets preferred, and no missing data. Whereas the SCDNR trammel net survey dataset has a long period of record and little missing data, many of the datasets initially identified for this project have less than 20 years of data and (or) large data gaps. Many of these datasets were associated with specific research projects that were either time or funding limited and are of shorter duration.

The lack of complete, long-term salinity datasets may result in researchers using spatially and temporally irregular datasets. CSIs were calculated for several such datasets (for example, the SCDNR trammel net surveys). Stacked graphs created using these surveys were found to be comparable to the CSI graphs produced for nearby USGS stations; however, statistical analysis should be performed to quantify these comparisons if further funding becomes available. In addition, CSI users who want to compare CSI results for multiple sites may find it difficult to identify stations with similar periods of record. Exclusion of drought or wet periods could alter the CSI results for stations with shorter periods of record compared to those with longer or more complete datasets.

The CSI R package accommodates datasets that are missing data by providing linear and spline interpolation functions. The user or data processor should determine if linear (or spline) interpolation is the appropriate method for the length of missing data. Other methods to address missing data questions warrant further investigation. For example, correlations between neighboring sites could be used to fill in large data gaps (that is, 1 month or longer). Such an approach might be appropriate for NERRS sites, which typically include three or four salinity monitoring stations. Conrads and Darby (2017) used simulation models and artificial neural network models to generate salinity estimates for the two stations used to develop the CSI.

Finally, opportunities to provide real-time CSIs may be limited by data availability. The USGS NWIS provides the largest network of continuous salinity data-collection and monitoring stations. NERRS sites have at least one active, real-time station where CSIs could be computed in addition to the USGS sites. Efforts to identify and vet additional salinity datasets could help to expand the availability of the tool for drought and resource management applications.

\section{Interpretation of Graphs}

Although CSI calculations and the generated values are fairly straightforward, many of the graphs generated through the R package are complex and difficult to interpret. Based on feedback from the Carolinas CSI working group and other potential users, a CSI User Guide (appendix 1) was developed to explain how the CSI is calculated and describe the various elements of the CSI graphs. This document is available on ScienceBase, the Coastal EDEN website, and the USGS South Atlantic Water Science Center website. Because the CSI is intended for a variety of audiences, both experts and nonexperts in drought monitoring, the User Guide is intended to facilitate the tool's use.

\section{Use in Drought and Ecological Monitoring}

The CSI was developed to characterize coastal drought, monitor changing salinity conditions, and improve understanding of the effects of changing salinities on fresh and saltwater ecosystems, fish habitat, and freshwater availability for municipal and industrial use. Conrads and Darby (2017) used waterquality stations in two large drainage basins - the Yadkin-Pee Dee and Savannah River Basins - in their initial efforts to develop the CSI (fig. 6). The current project expanded the number and geographic extent of CSI calculations that are available. This section identifies topics for consideration as users test and apply the CSIs for research, monitoring, and management purposes. 
The CSI's flexibility allows the index to be calculated and compared for different estuary types (for example, brackish, oligohaline, or mesohaline). Because the CSI is a site-specific index, however, users should account for the geologic, geographic, and management context of the watershed when interpreting and applying CSI values. In the Carolinas, for example, coastal watersheds vary from small tidal creeks, to Coastal Plain rivers, to large rivers that originate in the Piedmont or Blue Ridge provinces of North Carolina, South Carolina, and Georgia. These rivers and systems respond differently to precipitation, riverine flow, and tidal conditions, depending on the geologic setting. They also have different river and water management regimes. When comparing CSIs from multiple sites, the user should consider that different conclusions may be drawn from CSIs calculated within a few river miles along the same water body versus CSIs calculated across multiple water bodies within the same basin. Because the CSI represents the normalization of excursions from local conditions, interpretation of CSI values should not be strongly tied to the absolute magnitude of local salinity conditions.
CSI stacked graphs from the Winyah Bay, South Carolina, area (fig. 8) demonstrate how the magnitude and duration of salinity (or freshwater) conditions will vary according to a station's geographic, hydrologic, and salinity influences. Three NERRS stations (NIWDCWQ, NIWOLWQ, and NIWCBWQ) are in North Inlet, a small ocean-dominated estuary (Allen and others, 2014). Although connected to the larger Winyah Bay through a series of tidal creeks, water exchange between the two systems is limited by pronounced tidal nodes (Traynum and Styles, 2008), and freshwater input to the North Inlet estuary is mainly the result of very localized runoff from its limited surrounding uplands. As a result, the mean salinity value for these sites is between 32 and 33 parts per thousand (ppt) (fig. 9). The CSI results indicate the occurrence of the 2002, 2008, and 2012 drought periods; however, the magnitude and duration are less pronounced when compared to stations in the larger Winyah Bay estuary. Stacked graphs for these North Inlet stations also show extended wet periods in 2003-2004 and 2016. The NIWTAWQ station, in contrast, is located in Winyah Bay (fig. 8). This estuary is the third largest on the east coast, based on watershed area, and is fed by five

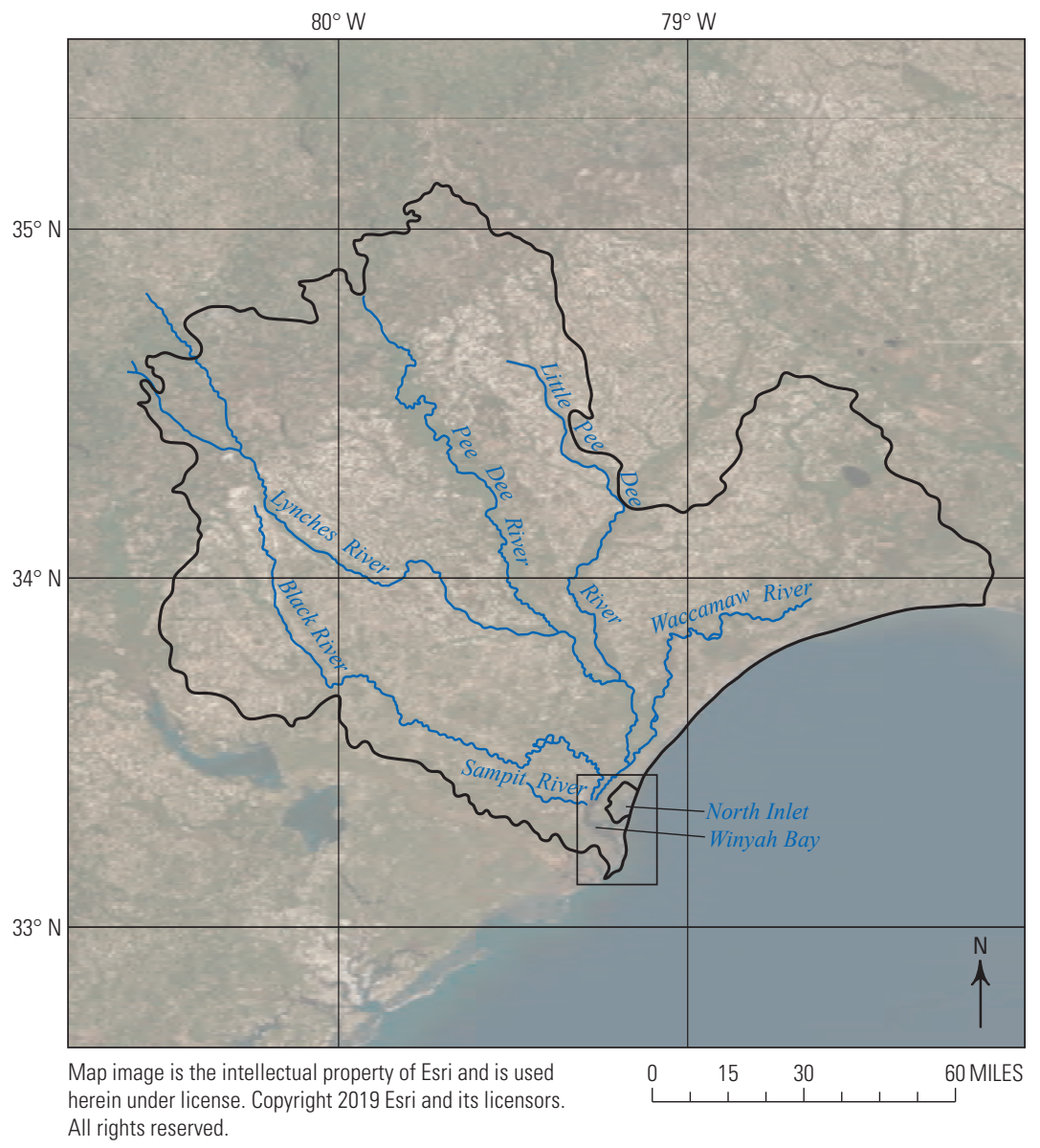

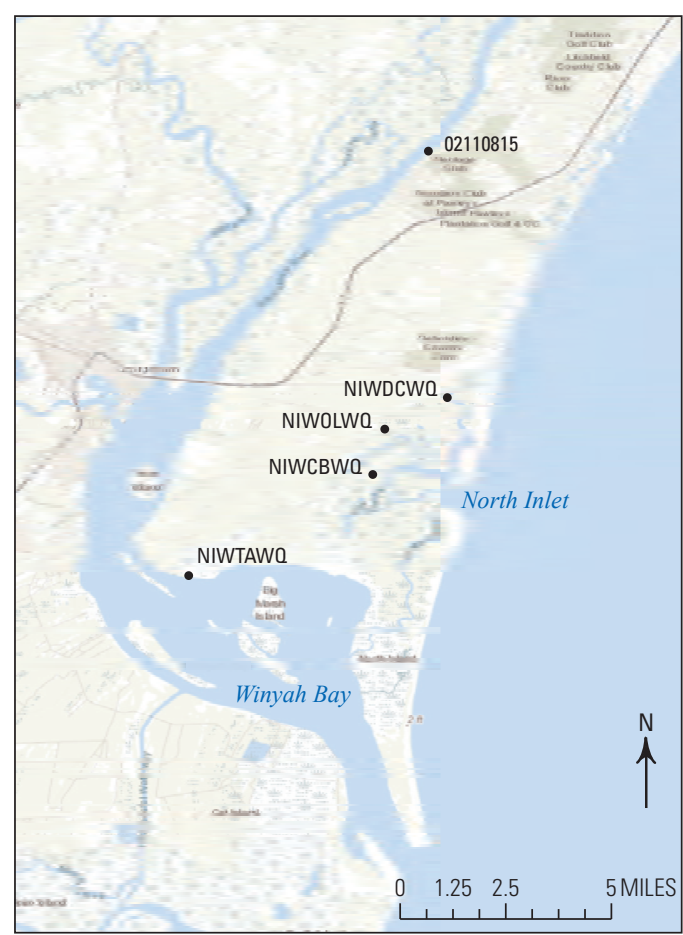

Sources: Esri, HERE, Garmin, Intermap, increment P Corp., GEBCO, USGS, FAO, NPS, NRCAN, GeoBase, IGN, Kadaster NL, Ordnance Survey, Esri Japan, METI, Esri China (Hong Kong), swisstopo, (c) OpenStreetMap contributors, and the GIS User Community

Figure 8. Locations of the $A$, watersheds and $B$, National Estuarine Research Reserve System stations near Winyah Bay and North Inlet, South Carolina. 
$\boldsymbol{A}$

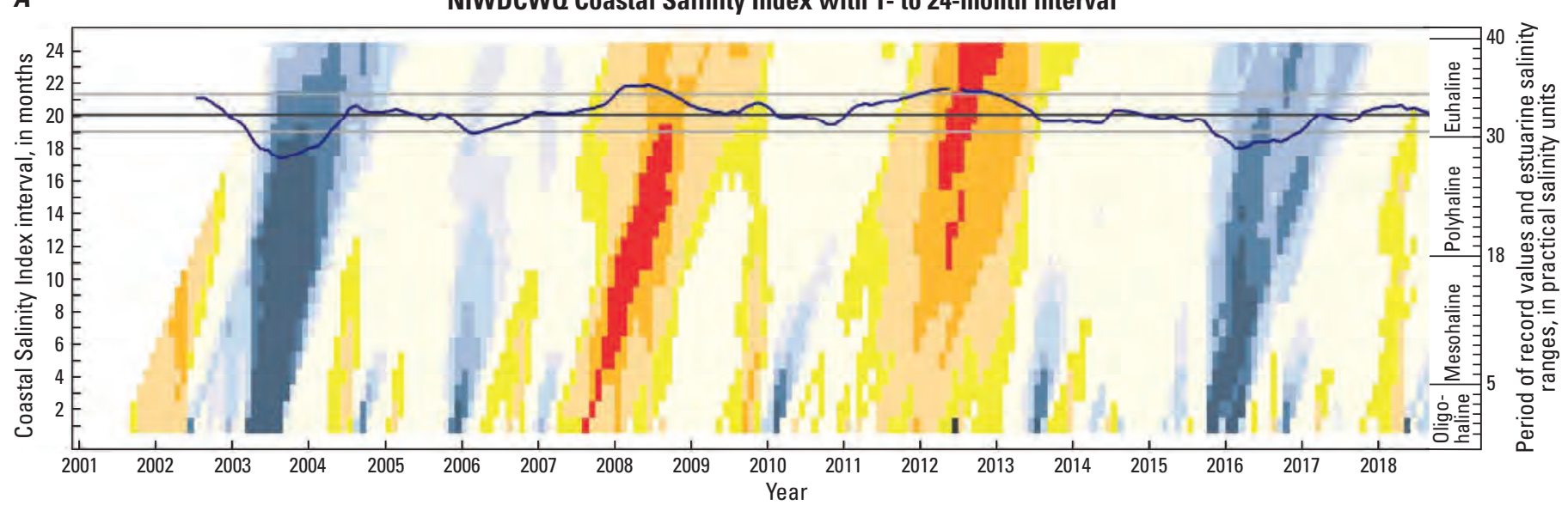

$\boldsymbol{B}$

NIWOLWQ Coastal Salinity Index with 1- to 24-month interval

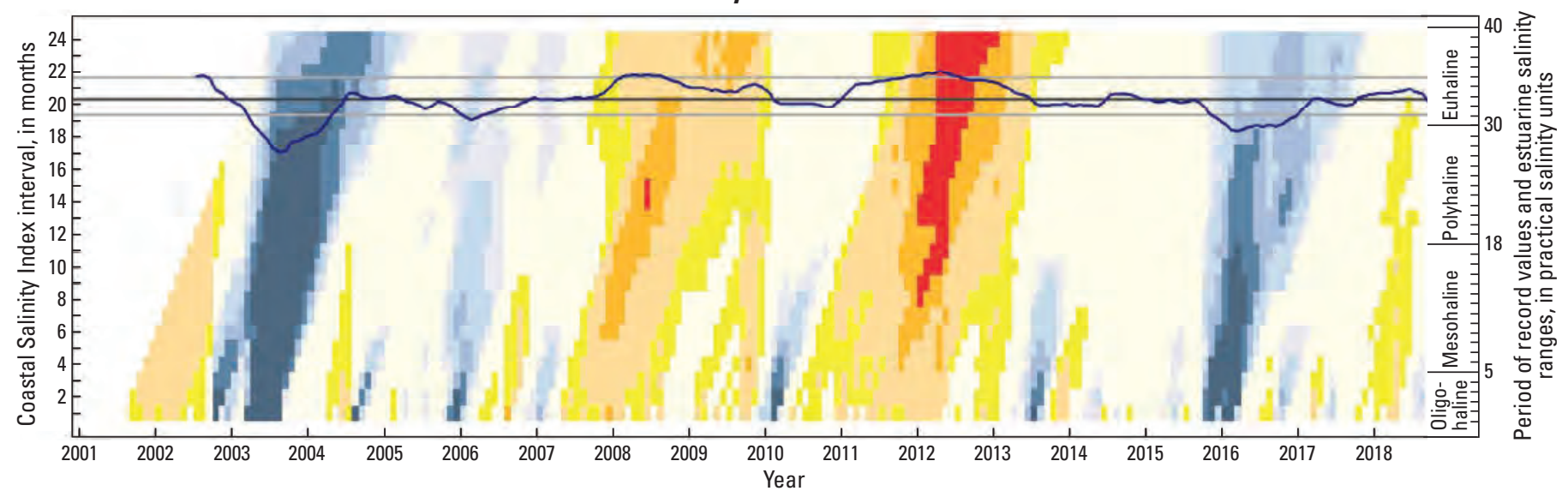

EXPLANATION

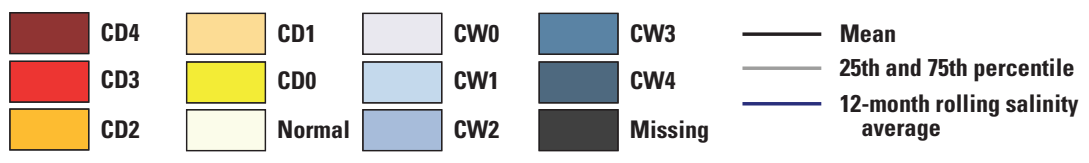

Figure 9. $A-D$, Coastal Salinity Index results for National Estuarine Research Reserve System stations near Winyah Bay and North Inlet, South Carolina. CD, coastal drought; CW, coastal wet. 
C

NIWCBW0 Coastal Salinity Index with 1- to 24-month interval

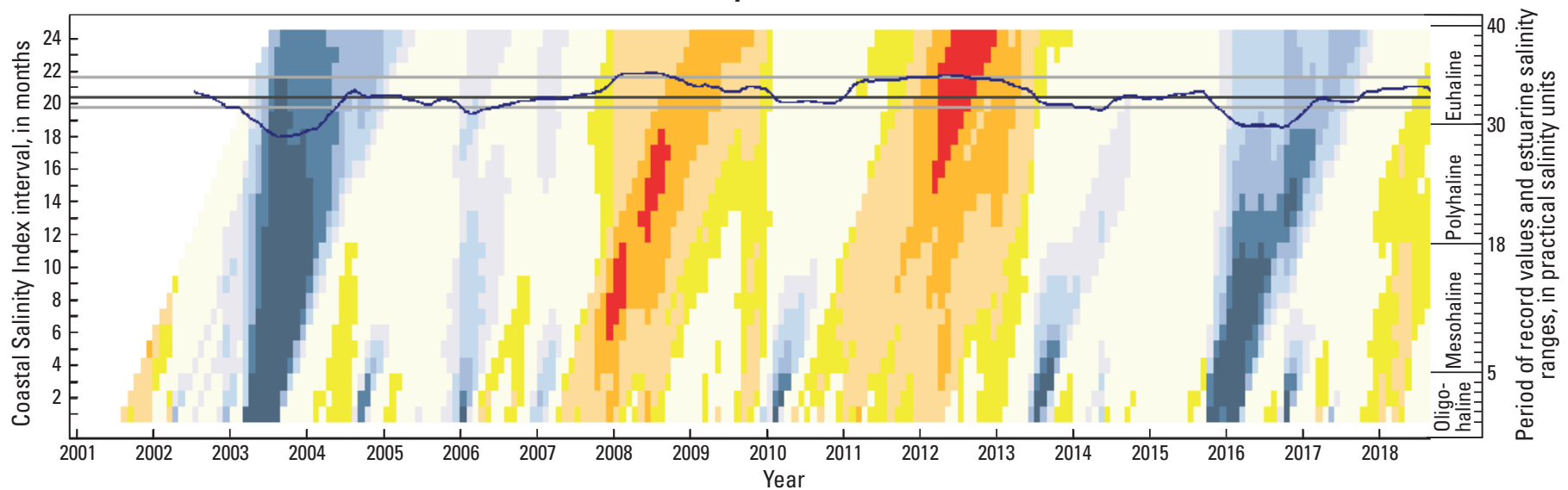

D

NIWTAW0 Coastal Salinity Index with 1- to 24-month interval

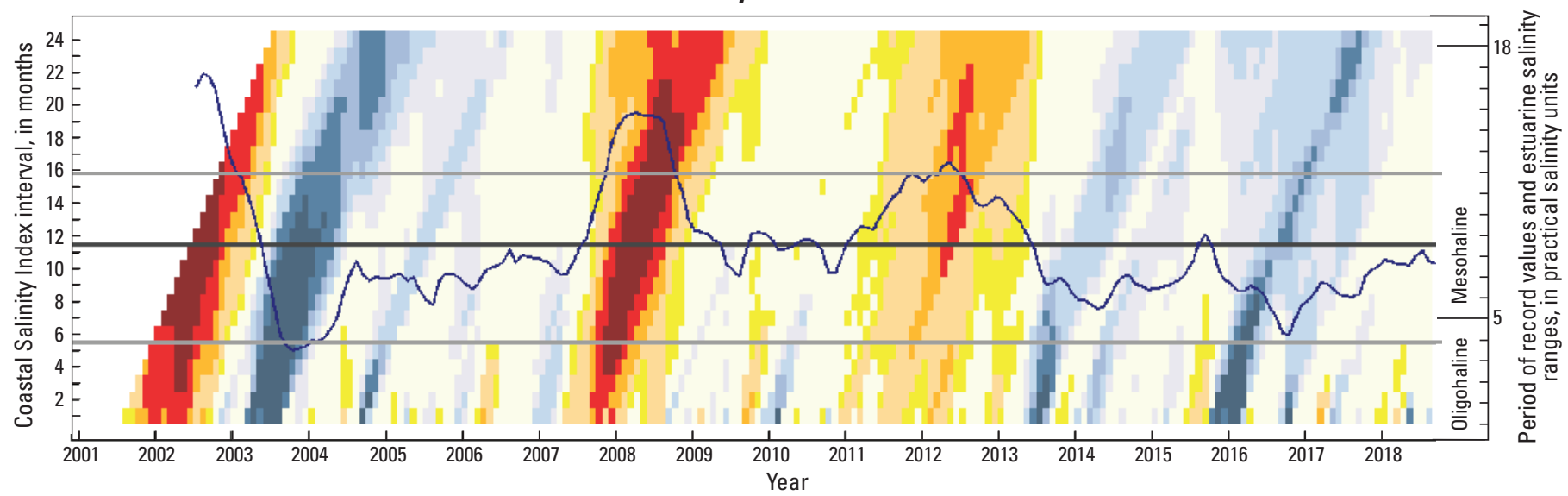

EXPLANATION

\begin{tabular}{|c|c|c|c|c|}
\hline CD4 & CD1 & CWO & CW3 & Mean \\
\hline CD3 & CDO & CW1 & CW4 & 25th and 75th percentile \\
\hline CD2 & Normal & CW2 & Missing & average \\
\hline
\end{tabular}

Figure 9. $A-D$, Coastal Salinity Index results for National Estuarine Research Reserve System stations near Winyah Bay and North Inlet, South Carolina. CD, coastal drought; CW, coastal wet.-Continued 
major rivers - the Black, Little Pee Dee, Pee Dee, Sampit, and Waccamaw Rivers (Allen and others, 2014). The larger watershed area and extensive freshwater input result in a mean salinity value of approximately $8.3 \mathrm{ppt}$ for the NIWTAWQ station. The CSI graph shows that this site experienced more severe drought conditions in 2002 and 2008 compared to the North Inlet sites, but conditions were similar for the remaining period of record. USGS station 02110815, which is upstream from Winyah Bay on the Waccamaw River (fig. 8), has a mean salinity value of $0.6 \mathrm{ppt}$. This station shows similar CSI response to the 2002 and 2008 droughts (fig. 10) as the Winyah Bay site (NIWTAWQ). Otherwise, the site does not appear to be as affected by dry $(2012)$ or wet $(2003,2016)$ conditions in other years.

The application of the CSI and the linkage to coastal resources addresses interests of many State and Federal agencies, universities, coastal resource managers, coastal ecologists, and the drought community. More work is needed to assess the use of the CSI for drought monitoring and to understand the linkages between drought, as expressed by the CSI, and estuarine systems and resources. With the CSI readily available to users, future work could include calculations throughout the coastal United States.

\section{Summary}

The Coastal Salinity Index (CSI) was created in 2013 to incorporate salinity, the primary stressor associated with coastal drought, into a unique drought monitoring index. For the CSI to be broadly useful as a drought monitoring tool, developmental efforts were required to expand comparisons and analyses beyond the two original sites used for CSI development. In 2017, the U.S. Geological Survey (USGS) received funding from the National Integrated Drought Information System to further develop and disseminate the CSI through three primary tasks: (1) building a unified CSI software platform, (2) releasing CSI calculations for many coastal locations, and (3) disseminating real-time, web-based CSI results. The geographic scope of this project is the southeastern and southern coastline of the United States, including the Atlantic and Gulf coasts, from Texas to North Carolina, as well as Puerto Rico.

The CSI data preparation, calculation, and visualization package was developed with the R scientific programing language and is available from the USGS GitLab website. The CSI R package includes functions to import salinity or specific

02110815 Coastal Salinity Index with 1- to 24-month interval
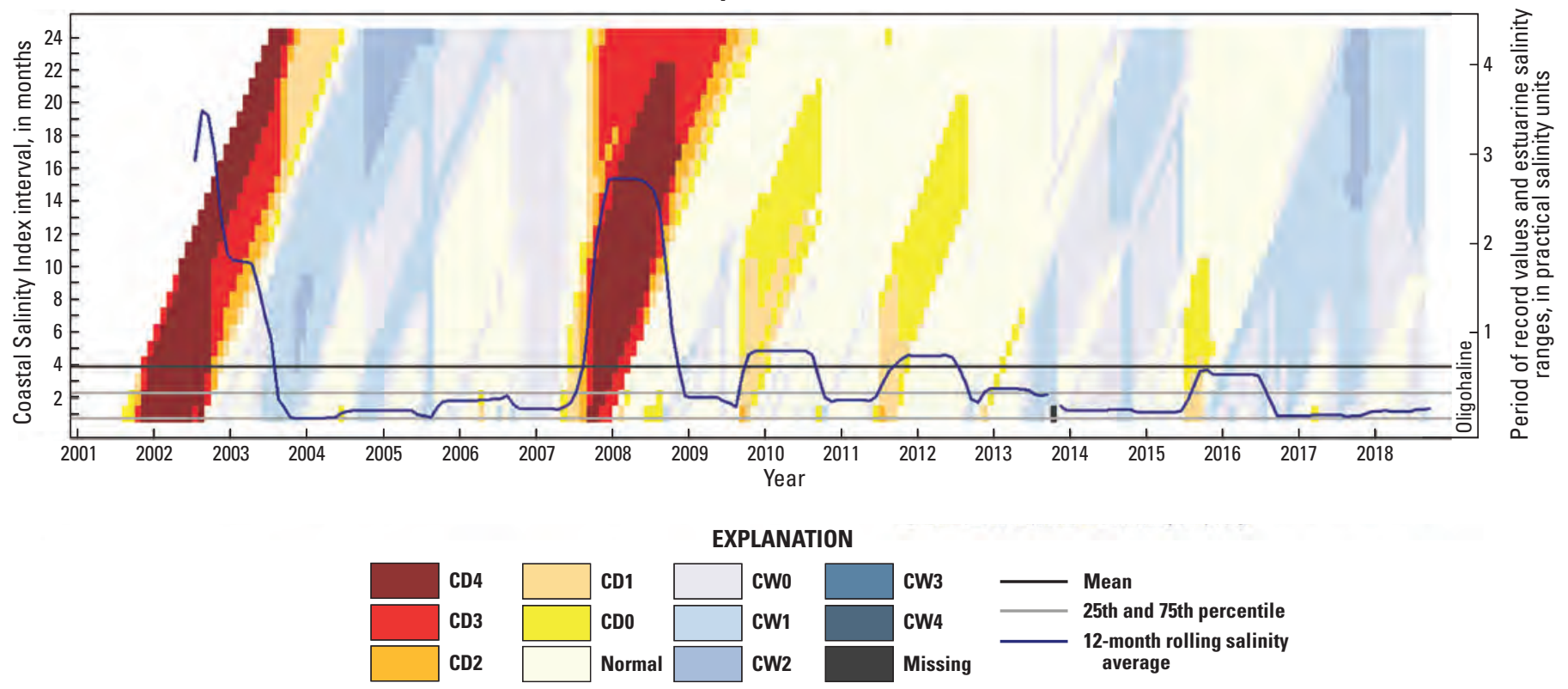

Figure 10. Coastal Salinity Index results for Waccamaw River near Pawley's Island, South Carolina (station 02110815). CD, coastal drought; CW, coastal wet. 
conductance data, interpolate missing values, and calculate, plot, and export CSI results.

To increase opportunities for linking the CSI to ecological response data, CSI calculations were completed for the full period of salinity record for 97 stations along the Gulf of Mexico and the southeastern Atlantic coast. The gages are in the coastal rivers, bays, estuaries, and sounds of North and South Carolina, Georgia, Florida, Alabama, Mississippi, Louisiana, Texas, and Puerto Rico. These sites consisted of USGS, National Estuarine Research Reserve System, Georgia Coastal Ecosystems Long Term Ecological Research Network, and Lower Colorado River Authority gages. These sites were selected because of their location, frequency of data collection, and relatively long periods of record. These CSI results are stored in the USGS ScienceBase data management platform (https://doi.org/10.5066/P9MQLNL2).

Real-time computations of the CSI are available on two USGS websites: the Coastal Everglades Depth Estimation Network website (https://sofia.usgs.gov/eden/coastal/) and the South Atlantic Water Science Center website (https://www2. usgs.gov/water/southatlantic/projects/coastalsalinity/home. php). These websites integrate computer scripts to acquire real-time salinity data from the USGS National Water Information System, load processed salinity data into a local database, compute gage CSI statistics for 1- to 24-month intervals, and create and display visualization products. The framework developed for the computation and dissemination of real-time CSIs includes documenting metadata, estimating periods of missing data, and archiving results. A User Guide, included in the appendix, provides an overview of the CSI and detailed explanations of the graphs generated by the $\mathrm{R}$ package.

Although the CSI could be applied to salinity data collected anywhere, the geographical extent of this investigation focused on identifying salinity sites from North Carolina to Texas, as well as in Puerto Rico. With the CSI readily available to users, future work could focus on testing the tool's utility with refuge managers, resource agencies, drought monitoring agencies, and researchers throughout the coastal United States.

\section{References Cited}

Allen, D.M., Allen, W.B., Feller, R.F., and Plunket, J.S., eds., 2014, Site profile of the North Inlet-Winyah Bay Estuarine Research Reserve: Georgetown, S.C., North Inlet-Winyah Bay National Estuarine Research Reserve, 417 p.

Arnott, S.A., Roumillat, W.A., Archambault, J.A., Wenner, C.A., Gerhard, J.I., Darden, T.L., and Denson, M.R., 2010, Spatial synchrony and temporal dynamics of juvenile red drum Sciaenops ocellatus populations in South Carolina, USA: Marine Ecology Progress Series, v. 415, p. 221-236, accessed July 8, 2019, at https://doi.org/10.3354/meps08710.
Barbier, E.B., Hacker, S.D., Kennedy, C., Koch, E.W., Stier, A.C., and Silliman, B.R., 2011, The value of estuarine and coastal ecosystem services: Ecological Monographs, vol. 81, no. 2, p. 169-193, accessed July 8, 2019, at https://doi. org/10.1890/10-1510.1.

Brennan, A., Dow, K., Lackstrom, K., Darby, L., and Ott, C., 2012, NIDIS Carolinas Drought Early Warning System-Supporting coastal ecosystem management-NIDIS Carolinas Drought Early Warning System Scoping Workshop, Wilmington, North Carolina, July 31-August 1, 2012: Columbia, S.C., National Integrated Drought Information System and Carolinas Integrated Sciences and Assessment, 28 p., accessed July 8, 2019, at https:/cisa. sc.edu/Pubs_Presentations_Posters/Reports/NIDIS $\% 20$ Carolinas\%20Drought $\% 20$ Early\%20Warning\%20 System\%20Scoping\%20Workshop\%20Report_Final.pdf.

Conrads, P.A., 2016, Development of a Coastal Drought Index using salinity data: U.S. Geological Survey data release, accessed July 8, 2019, at https://doi.org/10.5066/ F7TD9VDB.

Conrads, P.A., and Darby, L.S., 2017, Development of a Coastal Drought Index using salinity data: Bulletin of the American Meteorological Society, v. 98, no. 4, p. 753-766, accessed July 8, 2019, at https://doi.org/10.1175/

BAMS-D-15-00171.1.

Conrads, P.A., Rodgers, K.D., Passeri, D.L., Prinos, S.T., Smith, C., Swarzenski, C.M., and Middleton, B.A., 2018, Coastal estuaries and lagoons - The delicate balance at the edge of the sea: U.S. Geological Survey Fact Sheet 20183022, 4 p., accessed July 8, 2019, at https://doi.org/10.3133/ fs20183022.

Evenson, E.J., Orndorff, R.C., Blome, C.D., Bohlke, J.K., Herschberger, P.K., Langenheim, V.E., McCabe, G.J., Morlock, S.E., Reeves, H.W., Verdin, J.P., Weyers, H.S., and Wood, T.M., 2012, Strategic directions for U.S. Geological Survey water science, 2012-2022-Observing, understanding, predicting, and delivering water science to the Nation: U.S. Geological Survey Open-File Report 2012-1066, 42 p. [Also available at https://doi.org/10.3133/ofr20121066.]

McKee, T.B., Doesken, N.J., and Kleist, J., 1993, The relationship of drought frequency and duration to time scales, in Preprints, Eighth Conference on Applied Climatology, Anaheim, Calif., January 17-22, 1993: Boston, American Meteorological Society, p. 179-184.

Miller, R.L., Bradford, W.L., and Peters, N.E., 1988, Specific conductance; theoretical considerations and application to analytical quality control: U.S. Geological Survey Water Supply Paper 2311, 16 p. [Also available at https://doi. org/10.3133/wsp2311.] 
National Integrated Drought Information System, 2017a, Apalachicola Chattahoochee Flint River Basin Drought Early Warning System, 2017-2018 Strategic Plan: Boulder, Colo., National Integrated Drought Information System, 25 p., accessed July 8, 2019, at https://www.drought.gov/ drought/sites/drought.gov.drought/files/media/regions/ rdews/ACF/ACF\%20DEWS\%20Strategic\%20Plan\%20 2017\%20-\%202018.pdf.

National Integrated Drought Information System, 2017b, Coastal Carolinas Drought Early Warning System, 2017 2018 Strategic Plan: Boulder, Colo., National Integrated Drought Information System, 24 p., accessed July 8, 2019, at https://www.drought.gov/drought/sites/drought. gov.drought/files/media/regions/rdews/CoastalCarolina/ rpt-Carolinas-Strategic-Plan-2017.pdf.

National Integrated Drought Information System, 2017c, Southern Plains Drought Early Warning System, 2017-2018 Strategic Plan: Boulder, Colo., National Integrated Drought Information System, 31 p., accessed July 8, 2019, at https:// www.drought.gov/drought/sites/drought.gov.drought/ files/media/regions/rdews/SouthernPlains/Southern $\% 20$ Plains\%20DEWS\%20Strategic\%20Plan\%202017\%20-\%20 2018.pdf.

National Integrated Drought Information System, 2017d, The National Integrated Drought Information System Implementation Plan, December 2016 update: Boulder, Colo., National Integrated Drought Information System, 31 p., accessed July 8, 2019, at https://www. drought.gov/drought/sites/drought.gov.drought/files/ Implementation-Plan-December-2016-Update.pdf.

National Oceanic and Atmospheric Administration Office for Coastal Management, 2017, The National Estuarine Research Reserve System, Strategic Plan 2017-2022: Charleston, S.C., National Oceanic and Atmospheric Administration Office for Coastal Management, $9 \mathrm{p}$., accessed July 8, 2019, at https://coast.noaa.gov/data/docs/ nerrs/StrategicPlan.pdf.

Ostroff, A.C., Muhlfeld, C.C., Lambert, P.M., Booth, N.L., Carter, S.L., Stoker, J.M., and Focazio, M.J., 2017, USGS integrated drought science: U.S. Geological Survey Circular 1430, 24 p., accessed July 8, 2019, at https://doi. org/10.3133/cir1430.

Patino, E., Conrads, P., Swain, E., and Beerens, J., 2018, Everglades Depth Estimation Network (EDEN) - A decade of serving hydrologic information to scientists and resource managers (ver. 1.1, January 2018): U.S. Geological Survey Fact Sheet 2017-3069, 6 p., accessed July 8, 2019, at https://doi.org/10.3133/fs20173069.
Petkewich, M.D., McCloskey, B.J., Rouen, L.F., and Conrads, P.A., 2019, Coastal Salinity Index for monitoring drought: U.S. Geological Survey data release, https://doi. org/10.5066/P9MQLNL2.

R Core Team, 2013, R-A language and environment for statistical computing: Vienna, Austria, R Foundation for Statistical Computing, accessed July 8, 2019, at http:// www.R-project.org/.

Schemel, L., 2001, Simplified conversions between specific conductance and salinity units for use with data from monitoring stations: Interagency Ecological Program Newsletter, v. 14, no. 1, p. 17-18, accessed July 8, 2019, at https://pubs. er.usgs.gov/publication/70174311.

Telis, P.A., 2006, The Everglades Depth Estimation Network (EDEN) for support of ecological and biological assessments: U.S. Geological Survey Fact Sheet 2006-3087, 4 p. [Also available at https://doi.org/10.3133/fs20063087.]

Traynum, S., and Styles, R., 2008, Exchange flow between two estuaries connected by a shallow tidal channel: Journal of Coastal Research, v. 2008, no. 245, 1260-1268. [Also available at https://doi.org/10.2112/07-0840R.1.]

U.S. Environmental Protection Agency, 2009, National Estuary Program information booklet: Washington, D.C., U.S. Environmental Protection Agency, 18 p., accessed July 8, 2019, at https://www.epa.gov/sites/production/files/201509/documents/2009_12_23_estuaries_pdf_nep_brochure_ timeless_new.pdf.

U.S. Geological Survey, 2003, User's manual for the National Water Information System of the U.S. Geological SurveyAutomated data processing system (ADAPS), version 4.3: U.S. Geological Survey Open-File Report 03-123, 407 p., accessed December 2005, at https://doi.org/10.3133/ ofr03123.

U.S. Geological Survey, 2007, Facing tomorrow's challenges-U.S. Geological Survey science in the decade 2007-2017: U.S. Geological Survey Circular 1309, 67 p. [Also available at https://doi.org/10.3133/cir1309.]

U.S. Geological Survey, 2019, USGS water data for the Nation: U.S. Geological Survey National Water Information System database, accessed April 16, 2019, at https://doi. org/10.5066/F7P55KJN.

Wagner, R.J., Boulger, R.W., Oblinger, C.J., and Smith, B.A., 2006, Guidelines and standard procedures for continuous water-quality monitors-Station operation, record computation, and data reporting: U.S. Geological Survey Techniques and Methods, book 1, chap. D3, 83 p. [Also available at https://doi.org/10.3133/tm1D3.] 
World Meteorological Organization, 2012, Standardized Precipitation Index user guide: Geneva, Switzerland, World Meteorological Organization, WMO-No. 1090, 16 p.

World Meteorological Organization, and Global Water Partnership, 2016, Handbook of drought indicators and indices: Geneva, Switzerland, World Meteorological Organization and Global Water Partnership, Integrated Drought Management Tools and Guidelines Series 2, 45 p., accessed July 8, 2019, at http://www.droughtmanagement.info/literature/

GWP_Handbook_of_Drought_Indicators_and_Indices_2016.pdf.

Zeileis, A., Grothendieck, G., and Ryan, J.A., 2018, Package 'zoo': Vienna, Austria, R Foundation for Statistical Computing software documentation, 75 p., accessed February 26, 2019, at https://cran.r-project.org/web/packages/zoo/ zoo.pdf. 


\section{Appendix 1. Coastal Salinity Index User Guide}

The appendix is available for download at https://doi.org/10.3133/sir20191090. 
Comments or questions may be referred to:

South Atlantic Water Science Center, Director

U.S. Geological Survey

720 Gracern Road, Suite 129

Columbia, SC 29210

or visit our website at:

https://www.usgs.gov/centers/sa-water

Publishing support provided by the

Reston and West Trenton Publishing Service Centers 
